\title{
Factors Confounding the Athlete Biological Passport: A Systematic Narrative Review
}

\author{
Bastien Krumm ${ }^{1}$ and Raphael Faiss ${ }^{1,2^{*}}$ (D)
}

\begin{abstract}
Background: Through longitudinal, individual and adaptive monitoring of blood biomarkers, the haematological module of the athlete biological passport (ABP) has become a valuable tool in anti-doping efforts. The composition of blood as a vector of oxygen in the human body varies in athletes with the influence of multiple intrinsic (genetic) or extrinsic (training or environmental conditions) factors. In this context, it is fundamental to establish a comprehensive understanding of the various causes that may affect blood variables and thereby alter a fair interpretation of ABP profiles.

Methods: This literature review described the potential factors confounding the ABP to outline influencing factors altering haematological profiles acutely or chronically.

Results: Our investigation confirmed that natural variations in ABP variables appear relatively small, likely —at least in part-because of strong human homeostasis. Furthermore, the significant effects on haematological variations of environmental conditions (e.g. exposure to heat or hypoxia) remain debatable. The current ABP paradigm seems rather robust in view of the existing literature that aims to delineate adaptive individual limits. Nevertheless, its objective sensitivity may be further improved.
\end{abstract}

Conclusions: This narrative review contributes to disentangling the numerous confounding factors of the ABP to gather the available scientific evidence and help interpret individual athlete profiles.

Keywords: Athlete biological passport, Blood passport, Haematological variables

\section{Key Points}

- Through longitudinal, individual and adaptive monitoring of blood biomarkers, the haematological module of the athlete biological passport (ABP) has become a valuable tool in anti-doping efforts

- This literature review described the potential factors confounding the ABP to outline influencing factors altering haematological profiles acutely or chronically.

- While our results support the current ABP paradigm as rather robust to delineate adaptive individual lim-

\footnotetext{
*Correspondence: raphael.faiss@unil.ch

${ }^{2}$ Center of Research and Expertise in Anti-Doping Sciences - REDs,

University of Lausanne, Lausanne, Switzerland

Full list of author information is available at the end of the article
}

its, our work may contribute to disentangling the numerous confounding factors of the $\mathrm{ABP}$ to gather the available scientific evidence.

\begin{abstract}
Introduction
The concept of an athlete biological passport (ABP) was developed in the early 2000 s and officially introduced in 2009 [1], marking a turning point in the antidoping field. With the haematological and steroidal modules of the ABP, blood and urine variables were no longer utilised exclusively as direct screening parameters but as robust markers of either erythropoietic stimulation or steroid intake in individual, longitudinal monitoring [2]. This indirect screening approach is pertinent because indirect biological markers may reveal
\end{abstract}


abnormal variations in blood and urine potentially induced by doping [3].

The ABP is implemented with an adaptive probabilistic model based on a Bayesian approach [4] to determine the probability that an athlete's haematological variations are of prohibited origin [5]. Therefore, the effect of doping is not directly examined via the modification of the biological parameters but via the variation in the mean and standard deviation of these biomarkers [3]. When a first sample is collected, upper and lower thresholds are determined with population-based average benchmarks [5]. These individual limits are then subsequently and progressively adapted based on each athlete's values as additional samples are taken [5].

Fourteen parameters are currently recorded and analysed as part of the ABP haematological module in the online Anti-Doping Administration and Management System (ADAMS), which was developed and supported by the World Anti-Doping Agency (WADA). In ADAMS, two primary markers are monitored with remarkably strict operating guidelines [1]: haemoglobin concentration $([\mathrm{Hb}])$ and the erythropoiesis stimulation index 'OFF-Score' (OFFs), calculated as OFFs $=[\mathrm{Hb}]-60 \times \sqrt{ }$ Ret\%, including the percentage of reticulocytes (Ret\%) and $[\mathrm{Hb}]$ in $\mathrm{g} \mathrm{L}^{-1}$. An atypical passport finding (ATPF) is generated when a primary marker value falls outside the athlete's intra-individual range or when a longitudinal profile of primary marker values is outside expected ranges (sequence deviations), assuming a normal physiological condition' [1]. A level of specificity of $99 \%$ (outliers correspond to the values outside the 99\%-range i.e. at least 1:100 chance that this result is due to natural physiological origin) is required for the system to notify an ATPF.

The ABP uses this quantitative Bayesian model to detect an ATPF. Then, a qualitative expert review by the Athlete Passport Management Unit (APMU) handles administration of the individual passport before eventually requesting an evaluation by three independent ABP experts [4].

The latter expert review is essential because factors other than doping, such as physiological variations of biological origin or the results of an athlete's activity [3], may explain variations in haematological biomarkers. Interestingly, the plasma volume (PV) is at the core of many haematological changes [6], and $[\mathrm{Hb}]$, which is, by definition, measured as a concentration, may significantly vary and become difficult to interpret if PV changes [7]. In an athletic context, red blood cells diluted in plasma will be affected differently by conditions such as acute and chronic exercise, environmental factors or certain illnesses [8], and these conditions can be defined as confounding factors leading to a potential misinterpretation of the ABP biomarker variations [9].

The variability caused by confounders can, however, be significantly reduced by understanding the nature of these factors [3]. Four main sources of variation may be outlined: pre-analytical and analytical conditions, physical exercise, environmental conditions and individual characteristics. Currently, very strict guidelines for blood collection and analyses $[10,11]$ address the effect of preanalytical and analytical variations. In the current $\mathrm{ABP}$ operating guidelines [1], the notion of confounding factors is outlined only for the steroidal module (i.e. urine testing) of the ABP with reference to a recent review of confounders by Kuuranne et al. [12]. However, to the best of our knowledge, no systematic review has thoroughly examined the potential confounders affecting biomarkers of the haematological module. We hypothesise that the scientific evidence of confounders impacting blood profiles may challenge the current $\mathrm{ABP}$ approach. A review of the factors confounding hematological variables may thus help experts in their interpretation of abnormal $A B P$ profiles.

Therefore, this systematic review investigates the existing literature regarding the various factors influencing haematological markers. Its results, presented in a narrative format, aim to enhance $\mathrm{ABP}$ experts' prevailing understanding of these confounders.

\section{Methodological Approach \\ Information Sources}

Nine potential confounding factors of the haematological module were identified at the beginning of this review: doping practices, acute exercise, chronic training, exposure to a hot environment, exposure to a cold environment, exposure to a hypoxic environment, individual disorders or diseases, athlete characteristics and pre-analytical factors (Fig. 1).

A literature search was conducted in June 2020 on the PubMed and Google Scholar platforms with the above factors as research terms used in various combinations with the following terms: (haemoglobin OR haematocrit OR reticulocyte OR plasma volume) AND (haematology OR haematology OR haematological variation OR haematological parameter) AND (athlete) AND (sport).

\section{Study Selection}

From the results, the authors selected the most relevant articles considering the broad spectrum of different confounding factors potentially involved in blood variations. The main findings are presented in the result tables. Initially, all resulting titles and 


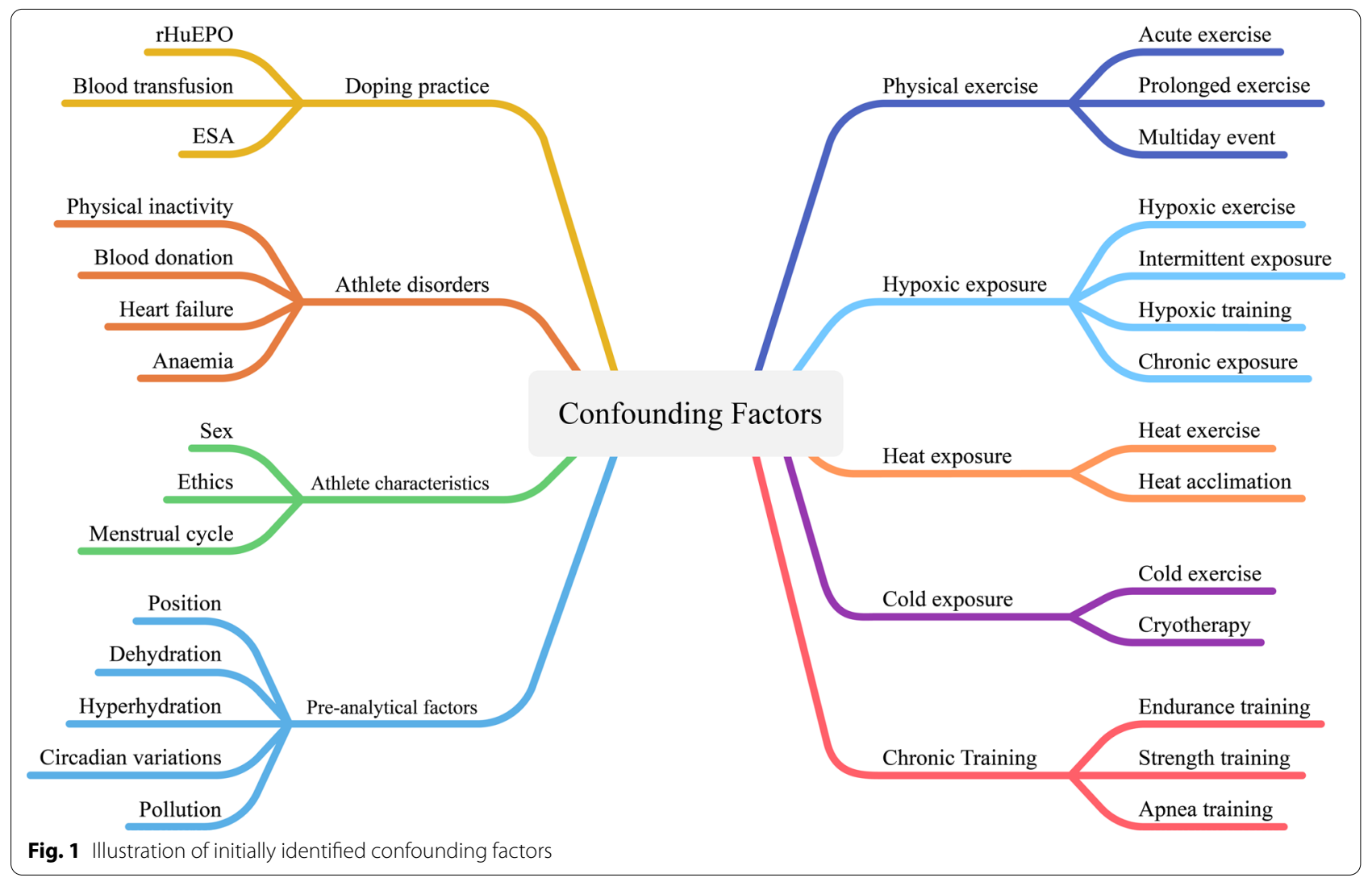

abstracts $(n=2325)$ were screened with adequate articles retained for further evaluation $(n=535)$. Grey literature was included by screening the references of the most relevant articles. Only studies in English with human subjects were considered for inclusion.

\section{Eligibility Criteria}

Studies where the effects of at least two confounding factors could not be clearly discriminated were excluded. Studies including both of the two primary ABP biomarkers (i.e. [Hb] and Ret\%) were identified in a first selection round $(n=124)$. At this stage, however, no studies related to climatic conditions (heat and cold exposure) matched with the above-mentioned inclusion criteria, despite the fact that these conditions exhibit an impact on PV variations affecting ABP markers. Hence, several articles related to environmental conditions but reporting no direct measurements of Ret\% or [Hb] were included in this review when PV changes (with a subsequent impact on $[\mathrm{Hb}]$ ) were deemed pertinent. The process resulted in the selection of 82 pertinent studies in an anti-doping context where added value for the interpretation of $A B P$ profiles was identified (as illustrated in the PRISMA flow diagram below in Fig. 2).

\section{Data Extraction}

With the existence of strict WADA guidelines ruling out confounders mentioned in the doping control forms [1], this narrative review will, however, focus mainly on confounding effects not addressed by the latter WADA rules. By reviewing the multiple confounders identified (Fig. 1), some pre-analytical factors (e.g. acute exercise or exposure to various extreme environments) may exert a significant influence on the haematological biomarkers, increasing the risk of misinterpretation of blood profiles. The period of influence these factors ranges from a few minutes (e.g. body position during sampling [13]) to a few hours (e.g. intense exercise [14]), and can, therefore, alter blood variables. For this review, we have considered the relative changes observed after an intervention or in a specific condition for the following physiological variables: [Hb], Ret\%, OFF-Score, haematocrit (Hct) and PV. 


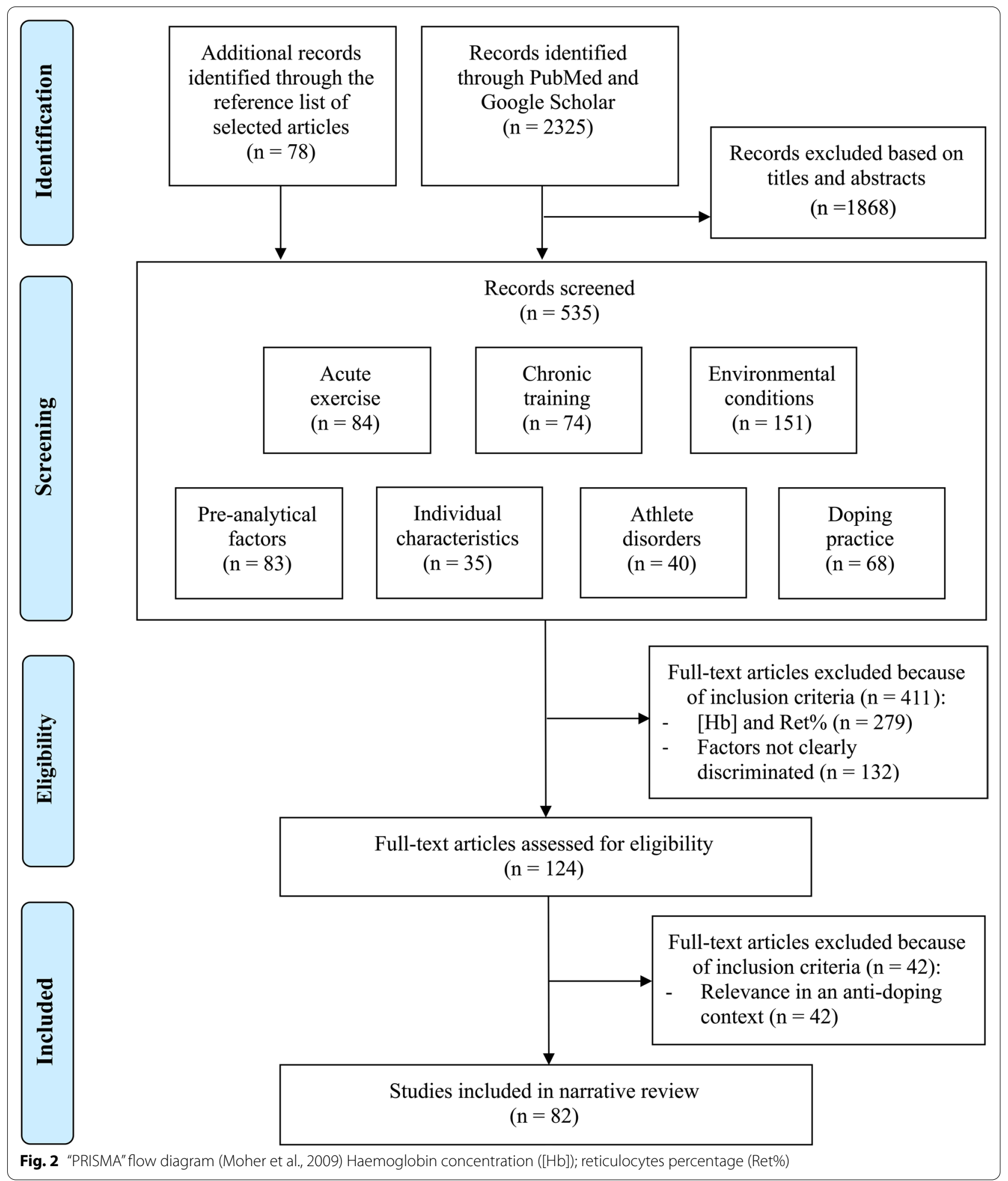

\section{Results}

The literature review indicates that doping practices represent a major confounder altering the ABP haematological variables most significantly (Tables 1 and 2). Other significant changes were observed after prolonged exercise (Tables 3 and 4), exercise training (Table 5), training periodisation (Table 6), thermal acclimation (Table 7) and hypoxic training (Table 8). Athlete characteristics 
Table 1 Changes of haematological variables related to rhEPO doping protocol

\begin{tabular}{|c|c|c|c|c|c|c|c|}
\hline Authors & Subjects & Interventions & {$[\mathrm{Hb}]$} & Ret $\%$ & OFFs & Hct & PV \\
\hline \multicolumn{8}{|l|}{ rhEPO doping } \\
\hline $\begin{array}{l}\text { Bejder, Aachmann- } \\
\text { Andersen et al. [15] }\end{array}$ & $\begin{array}{l}\text { Recreational athletes } \\
(n=16)\end{array}$ & $\begin{array}{l}\text { Sixteen subjects received } \\
\text { either } 65 \mathrm{IU} \text { rhEPO } \mathrm{kg}^{-1} \\
\text { every second day for } \\
2 \text { weeks (G1/normal-dose) } \\
\text { or } 390 \mathrm{IU} \text { rhEPO } \mathrm{kg}^{-1} \text { on } \\
3 \text { consecutive days (G2/ } \\
\text { high-dose) for } 13 \mathrm{~d} \text { in a } \\
\text { randomised, placebo- } \\
\text { controlled, double-blind } \\
\text { crossover design }\end{array}$ & $\begin{array}{l}=/= \\
(N S)\end{array}$ & $\begin{array}{l}\uparrow+81 \% \\
\uparrow+135 \%(11 \mathrm{~d}) \\
\downarrow-26 \% \\
\downarrow-21 \% \\
(25 \mathrm{~d})\end{array}$ & $\begin{array}{l}\downarrow-14 \% \\
\downarrow-21 \%(11 \mathrm{~d}) \\
\uparrow+18 \% \\
\uparrow+13 \% \\
(25 \mathrm{~d})\end{array}$ & - & - \\
\hline Bornø et al. [16] & $\begin{array}{l}\text { Recreational athletes } \\
(n=24)\end{array}$ & $\begin{array}{l}\text { Twenty-four human } \\
\text { subjects divided into three } \\
\text { groups with eight subjects } \\
\text { each were injected with } \\
\text { rhEPO. The G1 and G2 } \\
\text { groups received rhEPO } \\
\text { for a 4-week period } \\
\text { with } 2 \text { weeks of boost- } \\
\text { ing followed by } 2 \text { weeks } \\
\text { of maintenance and a } \\
\text { washout period of } 3 \text { weeks. } \\
\text { G3 received rhEPO for a } \\
10 \text {-week period: boost } \\
\text { (3 weeks/T1), maintenance } \\
\text { (7 weeks/T2) and washout } \\
(1 \text { week/T3) }\end{array}$ & $\begin{array}{l}= \\
(T 1) \\
\uparrow \\
(T 3)\end{array}$ & $\begin{array}{l}\uparrow \\
(T 1) \\
\downarrow \\
(T 3)\end{array}$ & $\begin{array}{l}\downarrow \\
(T 1) \\
\uparrow \\
(T 3)\end{array}$ & - & - \\
\hline Clark et al. [17] & $\begin{array}{l}\text { Recreational athletes } \\
(n=16)\end{array}$ & $\begin{array}{l}\text { Eight subjects were } \\
\text { assigned to receive six } \\
\text { subcutaneous high-doses } \\
\text { of } 250 \mathrm{IU} \cdot \mathrm{kg}^{-1} \text { of rhEPO } \\
\text { over } 2 \text { weeks (G1) while } \\
\text { eight other subjects were } \\
\text { assigned to receive six } \\
\text { high-doses plus nine } \\
\text { rhEPO micro-doses over a } \\
\text { further } 3 \text { weeks (G2) }\end{array}$ & $\begin{array}{l}\uparrow+1.5 \\
\uparrow+2.8 \mathrm{~g} \cdot d L^{-1} \\
(2 \text { weeks })\end{array}$ & $\begin{array}{l}+0.7 \% \\
+1.0 \% \\
(2 \text { weeks })\end{array}$ & $\begin{array}{l}\downarrow-37 p t \\
\downarrow-17 p t \\
\uparrow(2 \text { weeks }) \\
\uparrow(4 \text { weeks })\end{array}$ & $\begin{array}{l}\uparrow+6 \% \\
\uparrow+10 \% \\
(2 \text { weeks })\end{array}$ & $\begin{array}{l}\downarrow-6 d L \\
\downarrow-2 d L \\
(2 \text { weeks) }\end{array}$ \\
\hline Ashenden et al. [18] & $\begin{array}{l}\text { Recreational athletes } \\
(n=10)\end{array}$ & $\begin{array}{l}\text { Ten subjects were given } \\
\text { twice-weekly intravenous } \\
\text { micro-dose injections of } \\
\text { rhEPO for up to } 12 \text { weeks. } \\
\text { All subjects received the } \\
\text { same total quantity of } \\
\text { rhEPO (adjusted for body } \\
\text { weight) during the titration } \\
\text { phase }\end{array}$ & $\begin{array}{l}= \\
\text { (NS) }\end{array}$ & $\begin{array}{l}= \\
\text { (NS) }\end{array}$ & $\begin{array}{l}= \\
(\mathrm{NS})\end{array}$ & - & - \\
\hline Haile et al. [19] & Runners $(n=20)$ & $\begin{array}{l}\text { Twenty well-trained } \\
\text { Kenyan endurance run- } \\
\text { ners living and training } \\
\text { at approximately } 2150 \mathrm{~m} \\
\text { received rhEPO injections } \\
\text { of } 50 \mathrm{IU} \cdot \mathrm{kg}^{-1} \text { body mass } \\
\text { every } 2 \mathrm{~d} \text { for } 4 \text { weeks. This } \\
\text { cohort (KEN) was com- } \\
\text { pared with a previously } \\
\text { published cohort (SCO) } \\
\text { of } 19 \text { Scottish endurance- } \\
\text { trained men based at or } \\
\text { near sea level }\end{array}$ & $\begin{array}{l}\uparrow+10 \% \\
(4 \text { weeks) }\end{array}$ & $\begin{array}{l}\uparrow \\
(4 \text { weeks) }\end{array}$ & $\begin{array}{l}\downarrow \\
(4 \text { weeks) } \\
\uparrow \\
\text { (6 weeks) }\end{array}$ & $\begin{array}{l}\uparrow+10 \% \\
\text { (4 weeks) }\end{array}$ & - \\
\hline
\end{tabular}




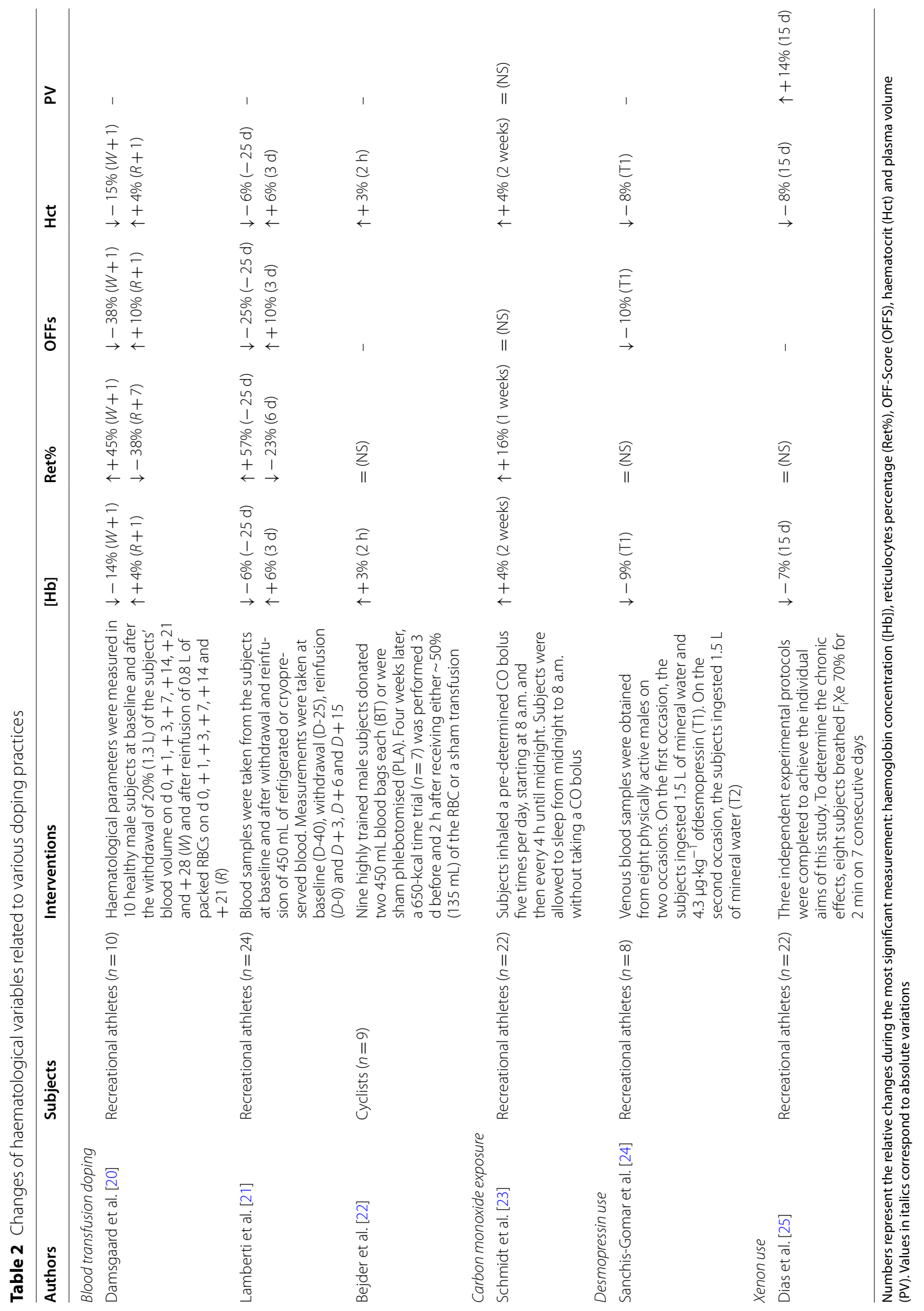




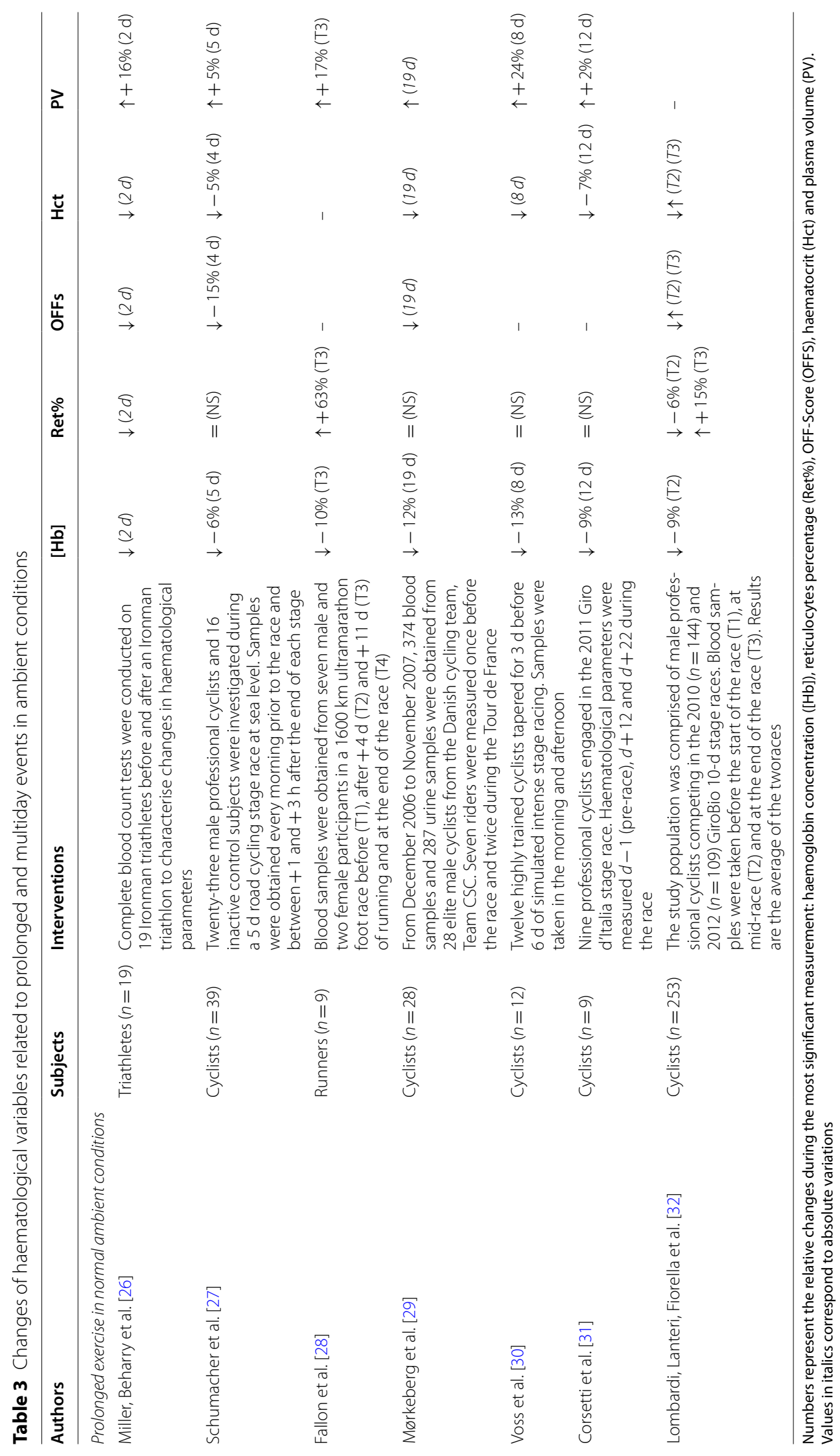




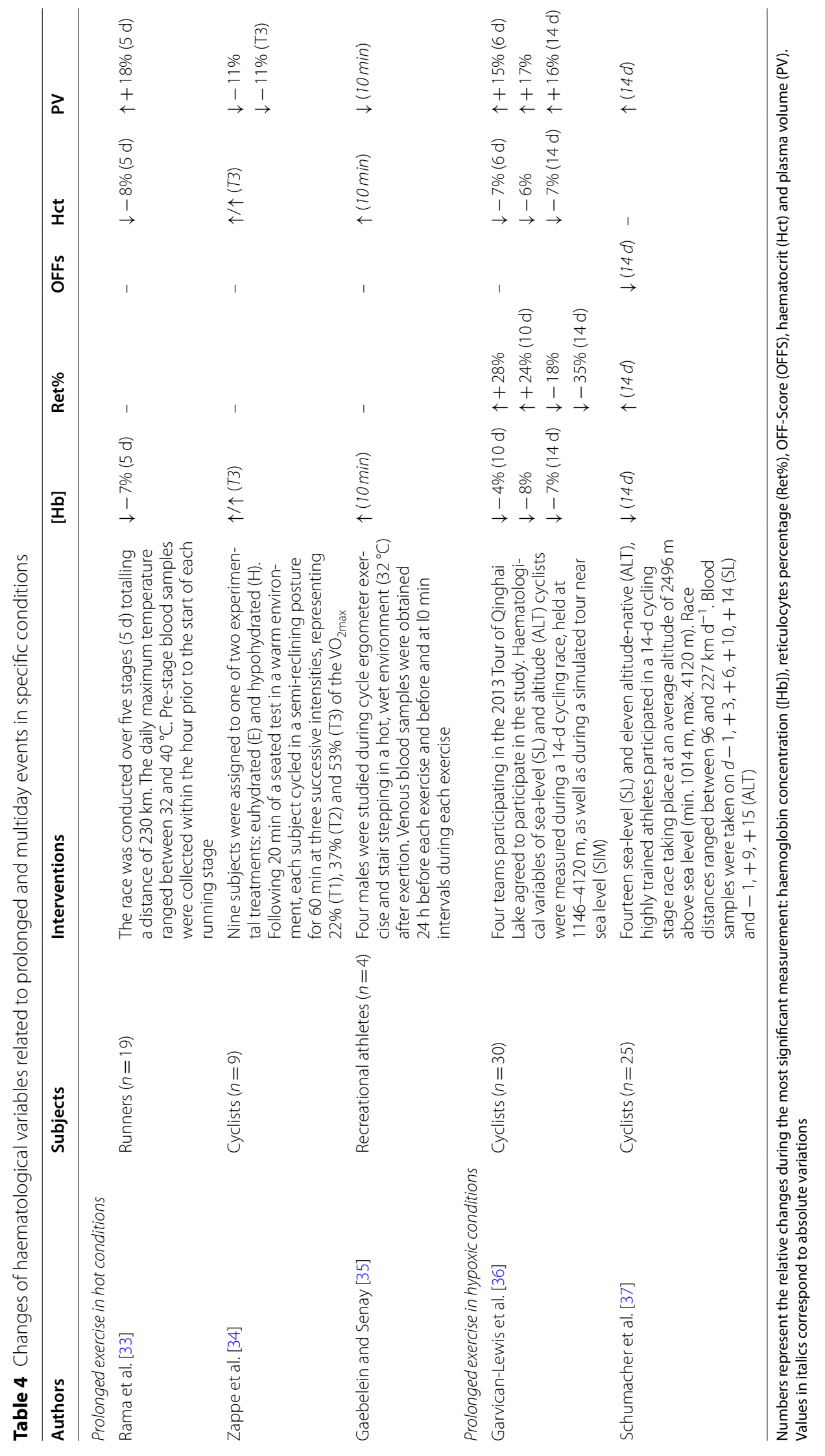


Table 5 Changes of haematological variables related to various forms of chronic training

\begin{tabular}{|c|c|c|c|c|c|c|c|}
\hline Authors & Subjects & Interventions & {$[\mathrm{Hb}]$} & Ret $\%$ & OFFs & Hct & PV \\
\hline \multicolumn{8}{|c|}{ Endurance training } \\
\hline Spodaryk [38] & $\begin{array}{l}\text { Various sports } \\
(n=39)\end{array}$ & $\begin{array}{l}\text { Haematological } \\
\text { and iron-related } \\
\text { parameters were } \\
\text { measured at rest } \\
\text { in } 39 \text { male athletes } \\
\text { from the Polish } \\
\text { team who partici- } \\
\text { pated in the } 1988 \\
\text { Seoul Olympics. } \\
\text { The athletes were } \\
\text { divided into two } \\
\text { groups: endurance- } \\
\text { trained subjects } \\
\text { (EN: cyclists, canoe- } \\
\text { ists and rowers) and } \\
\text { strength-trained } \\
\text { subjects (ST: wres- } \\
\text { tlers and judoka) }\end{array}$ & Lower (EN) & Higher (EN) & - & - & - \\
\hline Bejder et al. [39] & Cyclists $(n=11)$ & $\begin{array}{l}\text { Eleven high-level } \\
\text { competitive } \\
\text { cyclists were } \\
\text { investigated for } \\
3 \text { weeks. After initial } \\
\text { measurements } \\
\text { in week } 1 \text { (T1), } \\
\text { training load was } \\
\text { increased 250\% } \\
\text { in week } 2 \text { (T2) } \\
\text { followed by a } \\
\text { reversion to the } \\
\text { baseline training } \\
\text { load in week } 3 \text { (T3). } \\
\text { PV and haemato- } \\
\text { logical variables } \\
\text { were determined } \\
\text { frequently during } \\
\text { all weeks }\end{array}$ & $\downarrow-6 \%(\mathrm{~T} 2)$ & $\uparrow+15 \%(\mathrm{~T} 2)$ & $\downarrow-16 \%(\mathrm{~T} 2)$ & $\downarrow-5 \%$ (T2) & $\uparrow+10 \%(\mathrm{~T} 2)$ \\
\hline Green et al. [40] & $\begin{array}{l}\text { Recreational ath- } \\
\text { letes }(n=8)\end{array}$ & $\begin{array}{l}\text { Eight healthy, active } \\
\text { but untrained } \\
\text { males volunteered } \\
\text { for the training } \\
\text { study. The training } \\
\text { program involved } \\
8 \text { weeks of cycle } \\
\text { exercise, with each } \\
\text { training session } \\
\text { lasting for } 2 \mathrm{~h} \text { and } \\
\text { with the intensity } \\
\text { initially set at } 62 \% \\
\text { of each subject's } \\
\mathrm{VO}_{2 \text { max }} \text { Training } \\
\text { was performed on } \\
\text { a } 3-1-3 \text { cycle, with } \\
\text { exercise conducted } \\
\text { for } 3 \text { consecutive } \\
\text { days followed by } 1 \\
\text { d of inactivity and } \\
\text { another } 3 \text { consecu- } \\
\text { tive days of exercise }\end{array}$ & $\downarrow-4 \%$ (4 weeks) & $=(\mathrm{NS})$ & - & $\downarrow-5 \%$ (4 weeks) & $\uparrow+14 \%$ (4 weeks) \\
\hline
\end{tabular}


Table 5 (continued)

\begin{tabular}{|c|c|c|c|c|c|c|c|}
\hline Authors & Subjects & Interventions & {$[\mathrm{Hb}]$} & Ret\% & OFFs & Hct & PV \\
\hline Montero et al. [41] & $\begin{array}{l}\text { Untrained athletes } \\
(n=9)\end{array}$ & $\begin{array}{l}\text { Nine healthy, } \\
\text { untrained vol- } \\
\text { unteers under- } \\
\text { went supervised } \\
\text { endurance training } \\
\text { consisting of } \\
3-4 \times 60 \text { min cycle } \\
\text { ergometry ses- } \\
\text { sions per week for } \\
8 \text { weeks. Haema- } \\
\text { tological markers } \\
\text { were determined } \\
\text { before and at weeks } \\
+2(\mathrm{~T} 1),+4(\mathrm{~T} 2) \\
\text { and }+8(\mathrm{~T} 3) \text { of } \\
\text { training }\end{array}$ & $\downarrow-8 \%(\mathrm{~T} 1)$ & $=(\mathrm{NS})$ & - & $\downarrow-7 \%(\mathrm{~T} 1)$ & $\uparrow+16 \%(\mathrm{~T} 1)$ \\
\hline \multicolumn{8}{|l|}{ Apnea training } \\
\hline Revelli et al. [42] & Divers $(n=6)$ & $\begin{array}{l}\text { Six scuba divers } \\
\text { were tested before, } \\
\text { during and after } \\
\text { a } 14-\mathrm{d} \text { Guinness } \\
\text { saturation dive } \\
\text { (8-10 m). During } \\
\text { the dive, athletes } \\
\text { breathed air at } \\
\text { 1.8-2 ATA under the } \\
\text { control of a team of } \\
\text { physicians. Serum } \\
\text { parameters were } \\
\text { measured before } \\
\text { (T0), during (T1,T2) } \\
\text { and after the dive } \\
(\mathrm{T} 3, \mathrm{~T} 4)\end{array}$ & $=(\mathrm{NS})$ & $\downarrow-44 \%$ (T3) & - & $\downarrow-6 \%(T 2)$ & - \\
\hline
\end{tabular}

Numbers represent the relative changes during the most significant measurement: haemoglobin concentration ([Hb]), reticulocytes percentage (Ret\%), OFF-Score (OFFS), haematocrit $(\mathrm{Hct})$ and plasma volume $(\mathrm{PV})$. Values in italics correspond to absolute variations

(Tables 9 and 10) also produced significant changes. Less evident changes occurred due to pre-analytical conditions (Table 11) and acute exercise (Table 12).

First, differences observed in $[\mathrm{Hb}]$ related to doping practices ranged from $+10 \%$ following rhEPO doping [19] to $-14 \%$ after blood withdrawal [20]. Otherwise, the range of increase or decrease in $[\mathrm{Hb}]$ was $-5 \%$ due to certain pre-analytical conditions [79], $+16 \%$ after acute exercise [87], $-13 \%$ after prolonged exercise [30], $-8 \%$ after exercise training [41], $-2 \%$ after heat acclimation [51], $+9 \%$ after cold acclimation [57], $+4 \%$ after hypoxic training [60] and $-12 \%$ after blood donation [71].

Subsequently, a large amplitude was observed in the relative changes in Ret\% with increases up to $+135 \%$ after rhEPO doping [15] and decreases of $-38 \%$ observed after blood transfusions [20]. The range of increase or decrease in Ret\% notwithstanding doping was $+5 \%$ due to pre-analytical conditions [78], $+25 \%$ after acute exercise [83], $+63 \%$ after prolonged exercise [28], $-44 \%$ after apnea training [42], $+350 \%$ after hypoxic training [66] and $+27 \%$ after blood donation [70].
Differences in the OFF-Score as a result of doping practices ranged from $+18 \%$ after rhEPO doping [15] to $-38 \%$ after blood transfusion [20]. The margin of increase or decrease in the OFF-Score related to other factors was $-4 \%$ for pre-analytical conditions [80], $-15 \%$ after prolonged exercise [27], $-16 \%$ after exercise training [39] and $+22 \%$ after hypoxic training [58].

Hct differences ranged from $+10 \%$ after rhEPO intake [19] to $-15 \%$ after blood transfusion [20]. The range of Hct variations related to other confounding factors was $+4 \%$ [13] and $-4 \%$ [79] for pre-analytical conditions, $+12 \%$ after acute exercise [87], $-8 \%$ after prolonged exercise [33], $-7 \%$ after exercise training [41], $-2 \%$ after heat acclimation [52], $+5 \%$ after hypoxic training [58] and $+11 \%$ [72] and $-11 \%$ [71] after blood donation.

Finally, PV increased by $14 \%$ after chronic xenon inhalation [25]. The range of increase or decrease in PV linked to other parameters was $+4 \%$ for pre-analytical conditions [80], $-20 \%$ after acute exercise [87], $+24 \%$ after prolonged exercise [30], $+16 \%$ after exercise training 
Table 6 Changes in haematological variables related to training periodisation

\begin{tabular}{|c|c|c|c|c|c|c|c|}
\hline Authors & Subjects & Interventions & {$[\mathrm{Hb}]$} & Ret $\%$ & OFFs & Hct & PV \\
\hline \multicolumn{8}{|l|}{ Training content } \\
\hline Banfi and Del Fabbro [43] & Various sports $(n=63)$ & $\begin{array}{l}\text { The behaviour of reticu- } \\
\text { locyte and immature } \\
\text { reticulocyte fraction (IRF) } \\
\text { were analysed in top-level } \\
\text { athletes practising rugby } \\
\text { (RUG), ski (SKI), soccer (SOC) } \\
\text { and cycling (CYC) through- } \\
\text { out a competitive season. } \\
\text { Data were collected three } \\
\text { to four times: before the } \\
\text { start of the training period } \\
\text { (T1), at the beginning (T2), } \\
\text { in the middle (T3) and at } \\
\text { the end of the competitive } \\
\text { season (T4) }\end{array}$ & Lower (RUG) & $\begin{array}{l}\text { Lower (RUG) (CYC) } \\
\text { (SOC) Higher (SKI) }\end{array}$ & - & - & - \\
\hline $\begin{array}{l}\text { Abellan, Ventura, Pichini } \\
\text { et al. [44] }\end{array}$ & Various sports $(n=246)$ & $\begin{array}{l}\text { Haematological parameters } \\
\text { were measured in } 96 \text { elite } \\
\text { athletes of various sports. } \\
\text { Elite athletes participated in } \\
\text { different sports (swimming, } \\
\text { synchronised swimming, } \\
\text { taekwondo,rhythmic gym- } \\
\text { nastics, soccer, triathlon and } \\
\text { weightlifting) }\end{array}$ & $=(\mathrm{NS})$ & $=(\mathrm{NS})$ & $=(\mathrm{NS})$ & $=(\mathrm{NS})$ & $=(\mathrm{NS})$ \\
\hline Malcovati et al. [45] & Football players $(n=923)$ & $\begin{array}{l}\text { This study tested the effect } \\
\text { of age, ethnicity, exercise } \\
\text { modalities and training } \\
\text { phases on haematologic } \\
\text { parameters and then } \\
\text { estimated components } \\
\text { of variation. Differences } \\
\text { between low- (T1), int- (T2) } \\
\text { and high-season (T2) were } \\
\text { analysed }\end{array}$ & $\downarrow(T 2)$ & $\downarrow(T 2)$ & - & $\downarrow(T 2)$ & - \\
\hline Banfi et al. [46] & Rugby players $(n=19)$ & $\begin{array}{l}\text { Blood samples were col- } \\
\text { lected at four consecutive } \\
\text { training camps during a } \\
\text { whole competitive sea- } \\
\text { son-first, at the start of the } \\
\text { training period (T1), then } \\
\text { after the training meeting } \\
\text { (T2), after the first part of } \\
\text { the championships (T3) } \\
\text { and finally, at the end of the } \\
\text { championships (T4) }\end{array}$ & $\downarrow-3 \%(\mathrm{~T} 3)$ & $\downarrow-21 \%$ (T4) & - & $\downarrow-5 \%(\mathrm{~T} 3)$ & - \\
\hline Banfi et al. [47] & Skiers $(n=18)$ & $\begin{array}{l}\text { Haematological variations } \\
\text { of elite skiers were moni- } \\
\text { tored over four seasons. The } \\
\text { study sample included } 18 \\
\text { alpine skiers of the Italian } \\
\text { National Alpine Ski Team } \\
\text { (10 men and eight women). } \\
\text { Skiers began training in July } \\
\text { (T1) and competed from } \\
\text { November till April (T2) }\end{array}$ & $\downarrow(T 2)$ & $\uparrow(T 1)$ & - & - & - \\
\hline Taper period & & & & & & & \\
\hline
\end{tabular}


Table 6 (continued)

\begin{tabular}{|c|c|c|c|c|c|c|c|}
\hline Authors & Subjects & Interventions & {$[\mathrm{Hb}]$} & Ret\% & OFFs & Hct & PV \\
\hline Mujika et al. [48] & Runners $(n=8)$ & $\begin{array}{l}\text { After } 15 \text { weeks of training, } \\
\text { athletes completed a low- } \\
\text { volume taper, consisting } \\
\text { of either a } 75 \% \text { progressive } \\
\text { reduction in pre-taper, } \\
\text { low-intensity continuous } \\
\text { training or high-intensity } \\
\text { interval training. Blood sam- } \\
\text { ples were obtained before } \\
\text { (T1) and after (T2) the taper } \\
\text { period }\end{array}$ & $\downarrow-3 \%(\mathrm{~T} 2)$ & $\uparrow+44 \%(\mathrm{~T} 2)$ & - & $=(\mathrm{NS})$ & - \\
\hline Mujika et al. [49] & Runners $(n=10)$ & $\begin{array}{l}\text { After } 18 \text { weeks of training, } \\
\text { nine male runners were } \\
\text { assigned to a high- } \\
\text { frequency taper (HFT) or a } \\
\text { moderate frequency taper } \\
\text { (MFT), consisting of training } \\
\text { daily or resting every third } \\
\text { day of the taper. Blood sam- } \\
\text { ples were obtained before } \\
\text { (T1) and after (T2) the taper } \\
\text { period }\end{array}$ & $=(\mathrm{NS})$ & $=(\mathrm{NS})$ & - & $=(\mathrm{NS})$ & - \\
\hline
\end{tabular}

Numbers represent the relative changes during the most significant measurement: haemoglobin concentration ([Hb]), reticulocytes percentage (Ret\%), OFF-Score (OFFS), haematocrit (Hct) and plasma volume (PV). Values in italics correspond to absolute variations

[41], $+18 \%$ after heat acclimation [53] and $-14 \%$ after blood donation [72].

\section{Discussion}

Our study confirmed that the most obvious factor confounding the ABP biomarkers is blood doping. Doping protocols for erythropoiesis-stimulating substances (such as rhEPO injections) were generally structured with a treatment phase causing an increase in $[\mathrm{Hb}]$ and Ret\% (ON-phase), followed by a reversal trend when treatment was stopped (OFF-phase) [15-17], although significant inter-individual variability was observed [16]. Following blood withdrawal there should be a decrease in $[\mathrm{Hb}]$ and increase in Ret\%, with the opposite effect occurring after re-infusion [20, 21]. In addition, chronic exposure to low doses of carbon monoxide was recently shown to positively influence erythropoiesis and alter markers sensitive to PV variations [23, 94]. Conversely, repeated intake of desmopressin or chronic xenon inhalation induced haemodilution and decreased concentration-based biomarkers sensitive to PV shift $[24,25,95]$. However, micro-dosing doping schemes complicate the analysis of blood profiles due to limited haematological variations [22]. Indeed, the efficiency of the ABP appears significantly lower with low-volume autologous transfusion protocols due to several factors that may influence its sensitivity (e.g. timing of the sample collection) [22]. The current findings outline, for instance, the need for a strategy able to detect minor blood manipulations [96].
Numerous studies have highlighted specific blood variations as the result of pre-analytical factors including circadian modifications [73, 78] and prevention strategies such as sodium intake [79], overhydration [80] or posture adjustments [13]. In the same way, a temporary [Hb] increase caused by PV reduction was usually observed following acute exercise [7, 83, 85, 86] without affecting Ret\% in most cases [84]. Similarly, acute exposure to extreme environmental conditions, such as heat [87-90], cold [91, 92] or hypoxia [93], was reported to cause transitory PV shifts. Nevertheless, the strict WADA guidelines incorporate various pre-analytical precautions (e.g. reporting any exposure to hypoxia or extreme environment and other pathological conditions) to account for possible pre-analytical variations. However, other factors are not considered in the current model and may alter a proper interpretation of ABP profiles.

Prolonged exertion may affect an athlete's blood values with temporary but delayed effects persisting for several days [26], and these effects may occur and persist independent of environmental conditions. A progressive decrease of $[\mathrm{Hb}]$ was observed during multiday events (e.g. cycling stage races) $[27,29,30,36,37]$, although other studies observed a stabilisation over time [31,33] or even an increase towards the end of the competition [32]. The Ret\% was mostly unaffected by participation in multiday events [27], although some variations (unrelated to an erythropoietic stimulation) were reported [26, 28]. 


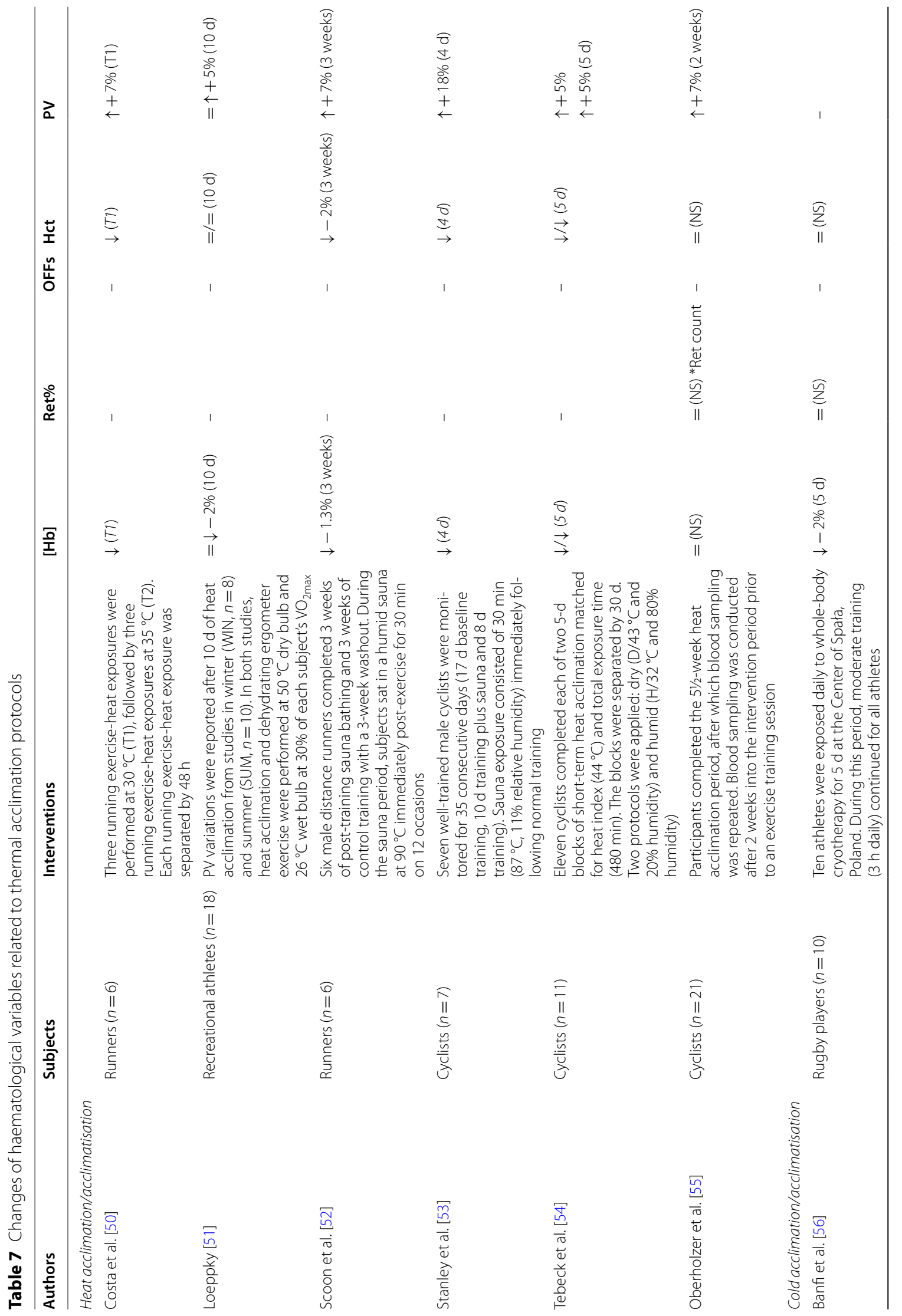




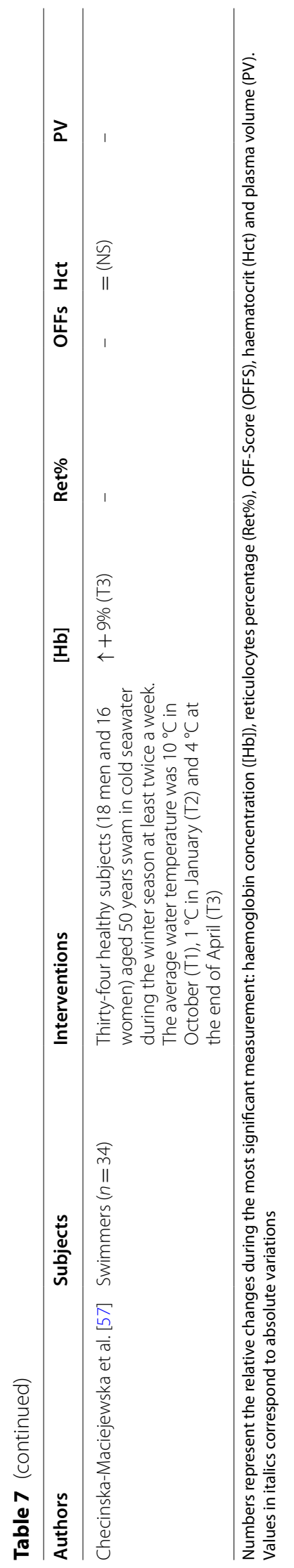




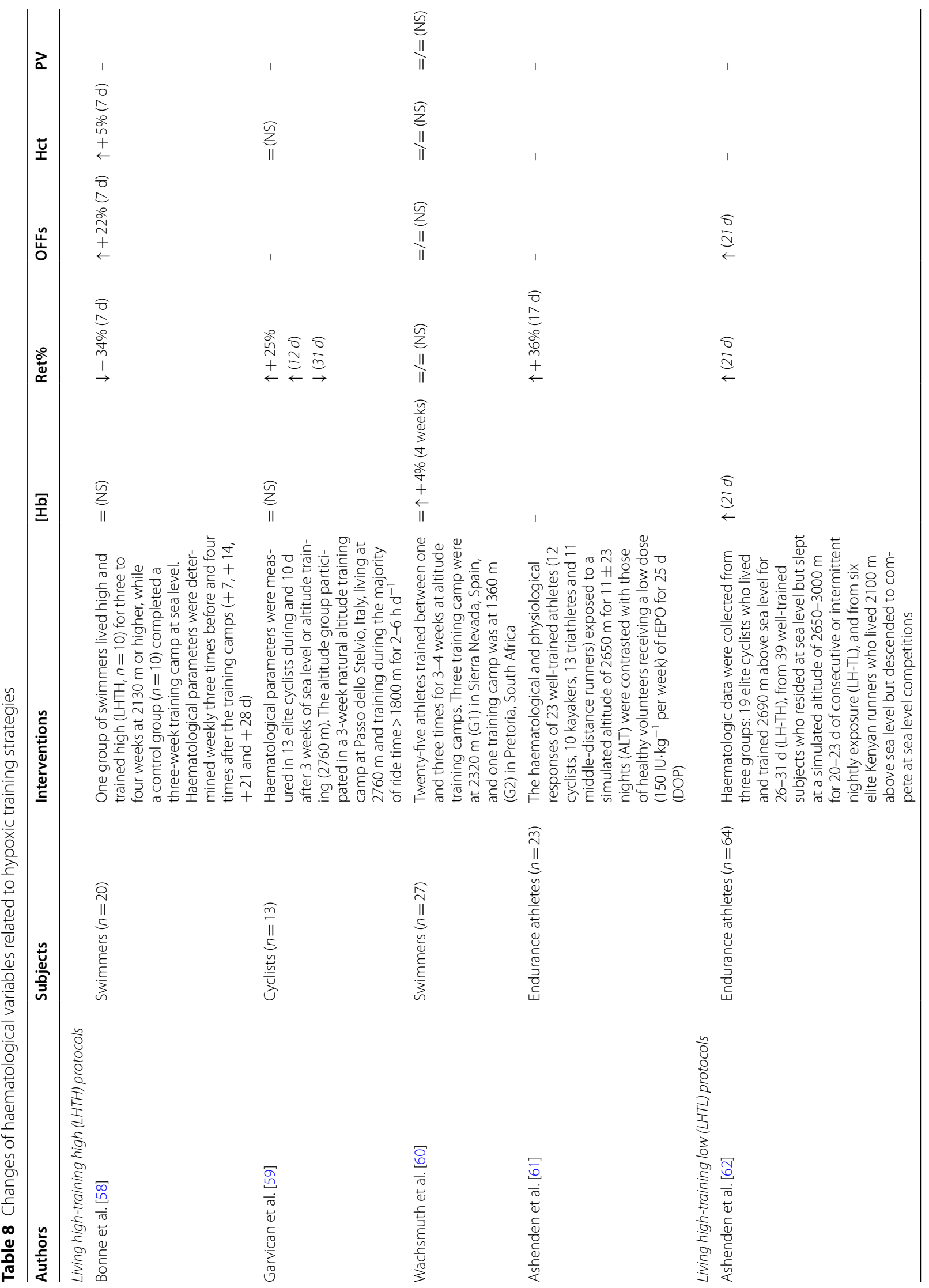




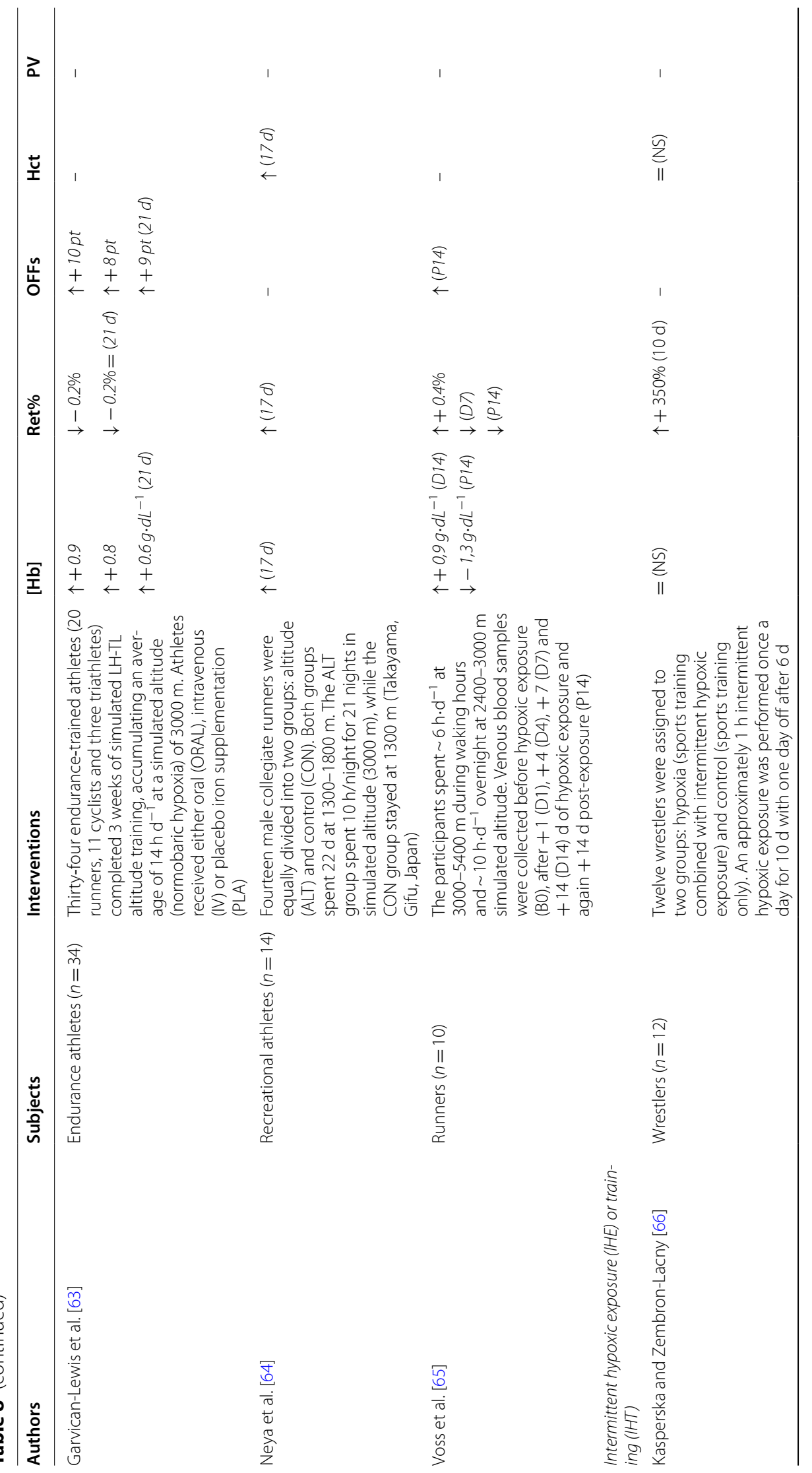




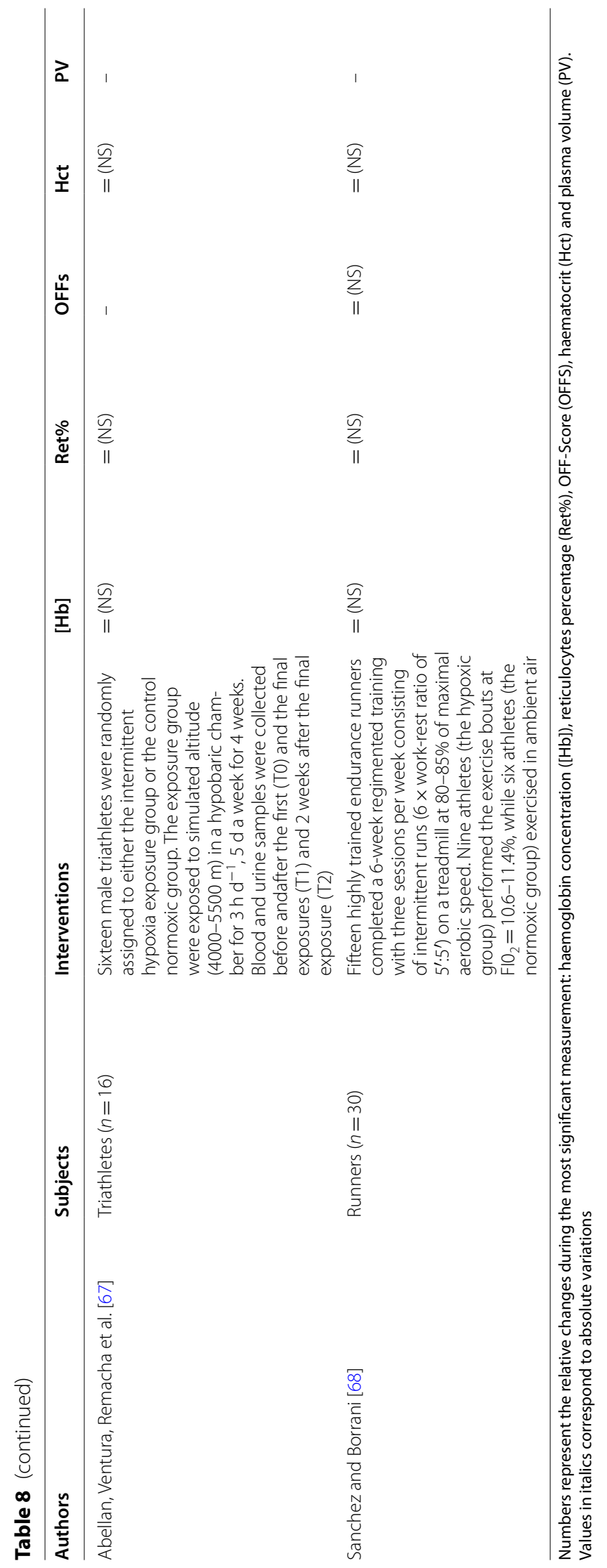




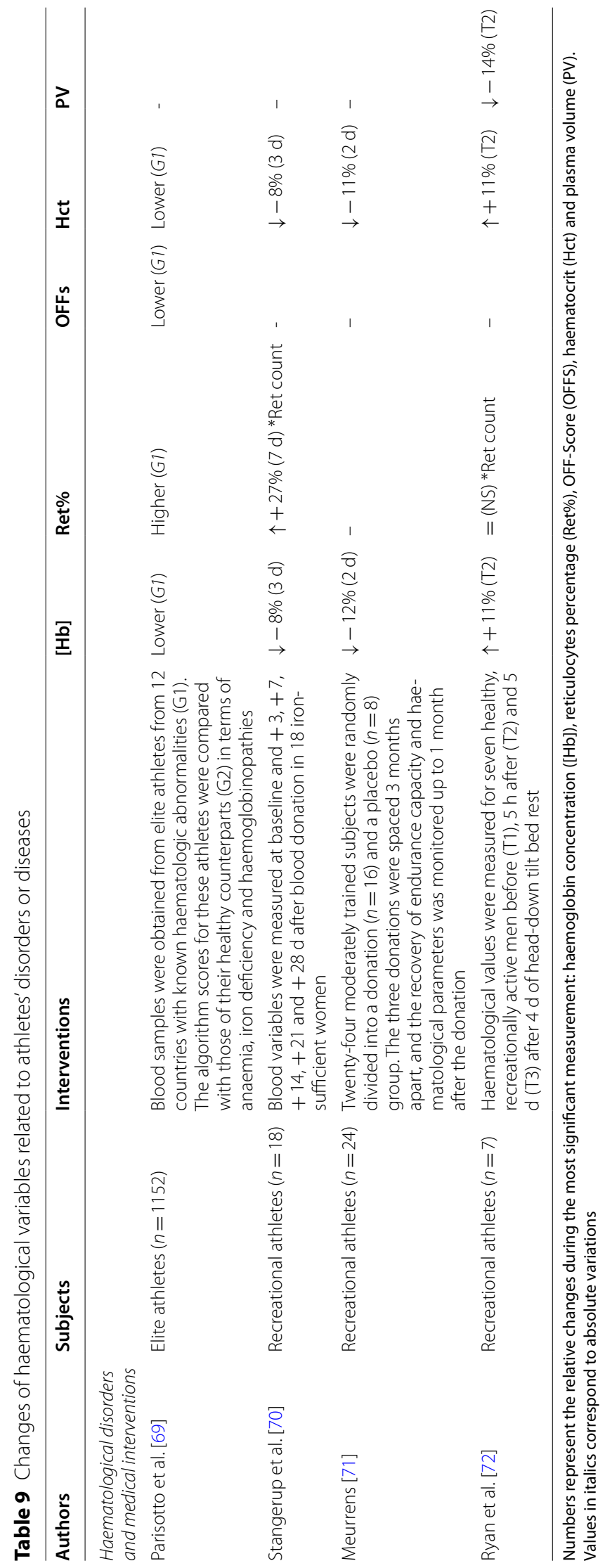


Table 10 Changes in haematological variables related to athletes' characteristics

\begin{tabular}{|c|c|c|c|c|c|c|c|}
\hline Authors & Subjects & Interventions & {$[\mathrm{Hb}]$} & $\operatorname{Ret} \%$ & OFFs & Hct & PV \\
\hline \multicolumn{8}{|l|}{ Genetic characteristics } \\
\hline Robinson et al. [73] & $\begin{array}{l}\text { Track and } \\
\text { field athletes } \\
(n=3683)\end{array}$ & $\begin{array}{l}\text { Reference ranges in top-level } \\
\text { track and field athletes were } \\
\text { determined for biomarkers of } \\
\text { altered erythropoiesis considering } \\
\text { various factors such as gender } \\
\text { (M/F), age, endurance (E) or } \\
\text { non-endurance (NE) disciplines, } \\
\text { detailed sport disciplines, the ori- } \\
\text { gin of the athletes (African [AFR], } \\
\text { South America [SAF], European } \\
\text { [EUR], Oceania [OCE]) and the } \\
\text { time of blood sampling }\end{array}$ & $\begin{array}{l}\text { Higher }(M)(A F R) \\
(S A F) \text { Lower }(O C E)\end{array}$ & Lower $(M)$ & $=(\mathrm{NS})$ & - & - \\
\hline Mullen et al. [74] & $\begin{array}{l}\text { Recreational } \\
\text { athletes } \\
(n=17)\end{array}$ & $\begin{array}{l}\text { Seventeen women with regular } \\
\text { menses were included. Blood } \\
\text { samples were collected once a } \\
\text { week for two consecutive cycles } \\
\text { and analysed for haematological } \\
\text { parameters. Menstrual phases } \\
\text { were hormonally determined: fol- } \\
\text { licle (T1), ovulatory (T2) and luteal } \\
\text { phases (T3) }\end{array}$ & $=(\mathrm{NS})$ & Lower - 19\% (T1) & $=(\mathrm{NS})$ & $=(\mathrm{NS})$ & - \\
\hline Lobigs [75] & $\begin{array}{l}\text { Recreational } \\
\text { athletes } \\
(n=2222)\end{array}$ & $\begin{array}{l}\text { Reference intervals of healthy } \\
\text { athletes were established for } \\
13 \text { haematological parameters. } \\
\text { Participants were subsequently } \\
\text { characterised into five major } \\
\text { ethnic groups: Arabic (G1), Asian } \\
\text { (G2), Black (G3), White (G4) and } \\
\text { Mixed (G5) }\end{array}$ & Lower (G1) & Lower (G3) & - & Lower (G1) & - \\
\hline Steiner and Wehrlin [76] & $\begin{array}{l}\text { Endurance } \\
\text { athletes } \\
(n=92)\end{array}$ & $\begin{array}{l}\text { Blood parameters were measured } \\
\text { in three endurance athlete } \\
\text { groups: AG16 }(n=14), A G 21 \\
\text { ( } n=14) \text { and } A G 28(n=16) \text {, as well } \\
\text { as in three age-matched control } \\
\text { groups ( }<2 \text { h endurance training } \\
\text { per week): CG16 }(n=16), C G 21 \\
(n=15) \text { and CG28 }(n=16)\end{array}$ & Lower - 6\% (AG16) & $=(\mathrm{NS})$ & $=(\mathrm{NS})$ & Lower - 6\% (AG16) & $=(\mathrm{NS})$ \\
\hline Steiner et al. [77] & $\begin{array}{l}\text { Endurance } \\
\text { athletes } \\
(n=22)\end{array}$ & $\begin{array}{l}\text { Several venous blood param- } \\
\text { eters were assessed in ten male } \\
\text { adolescent endurance athletes } \\
\text { (five XC-skiers and five triathletes) } \\
\text { at seven time points in 6-month } \\
\text { intervals, resulting in a monitoring } \\
\text { phase of } 3 \text { years }\end{array}$ & $=(\mathrm{NS})$ & $=(\mathrm{NS})$ & - & $=(\mathrm{NS})$ & $\uparrow(3 y)$. \\
\hline
\end{tabular}

Numbers represent the relative changes during the most significant measurement: haemoglobin concentration ([Hb]), reticulocytes percentage (Ret\%), OFF-Score (OFFS), haematocrit (Hct) and plasma volume (PV). Values in italics correspond to absolute variations

In contrast to transient variations caused by acute exercise, PV was shown to expand over a few weeks of endurance training, thereby reducing [Hb] [39-41]. Interestingly, multiple studies also reported a noticeable variation in Ret\% after a few weeks of training [39-41]. Furthermore, acute and chronic training loads, the competition calendar and training periodisation were shown to significantly alter blood variables included in the ABP [43, 48, 49, 97], with [Hb] decreases most likely during periods with the highest training loads [46]. In a recent 12-month longitudinal study of elite cyclists addressing the influence of training on ABP variables, no ATPF was observed, underlining the relative robustness of the ABP adaptive model in incorporating varying training loads [97].

Various environmental conditions (e.g. hypoxic or hot environments) are currently gaining popularity as additional training stimuli [98] with a putative effect on fluid balance [99]. PV increase represents one of the main physiological adaptations that occur during heat 
Grum and Tais Sports Med - Open <wide> (2021) 7:65

Page 20 of 30

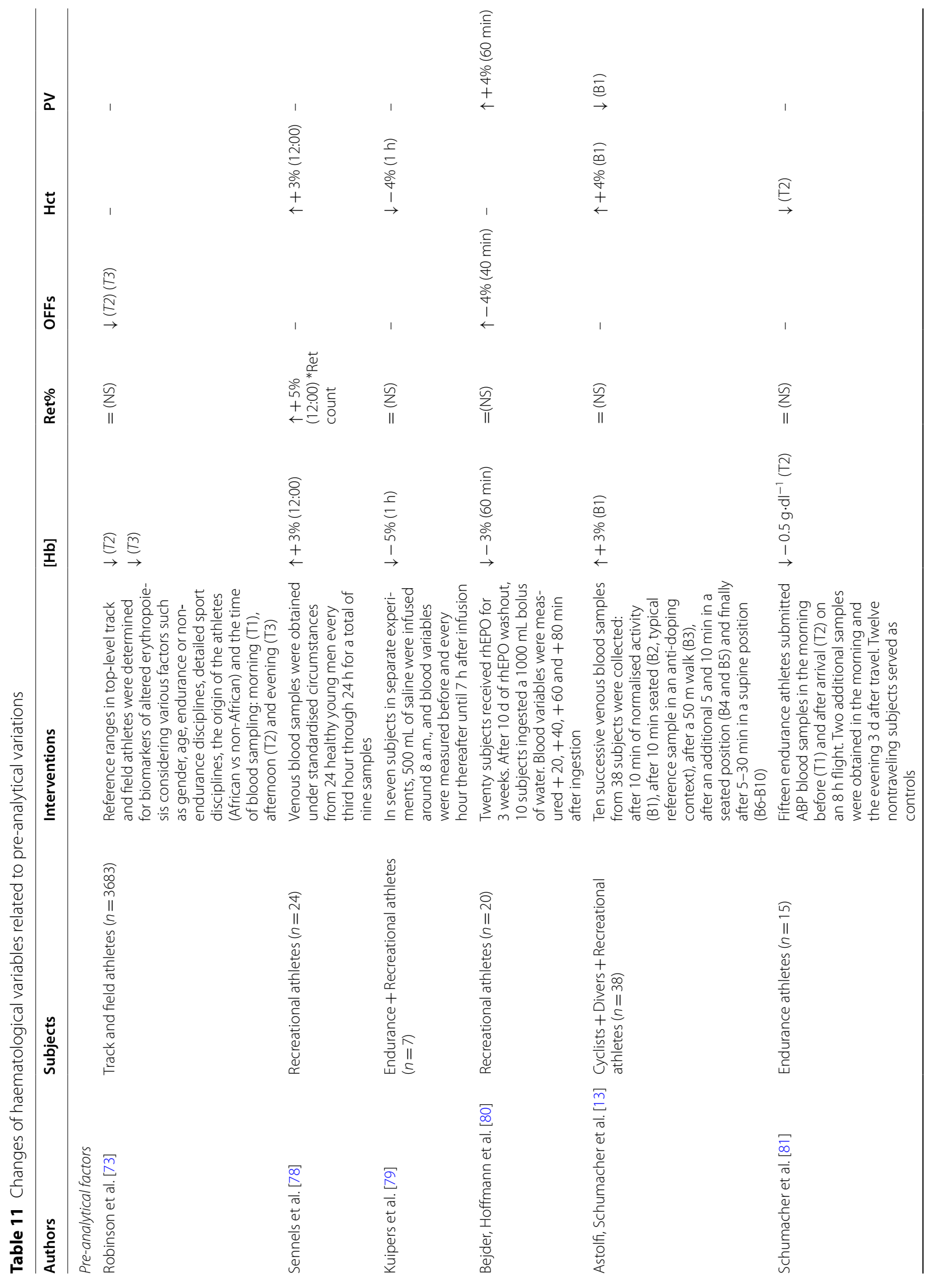




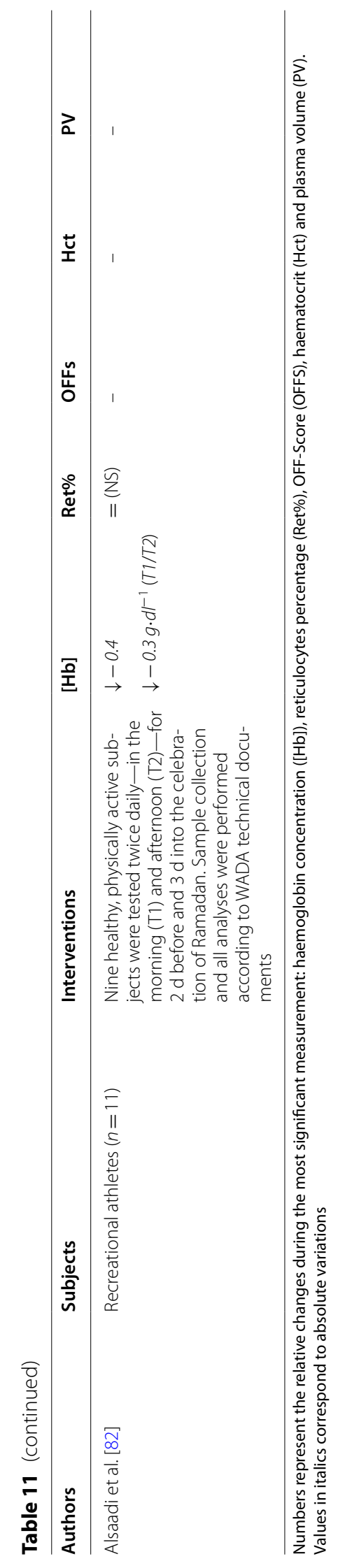




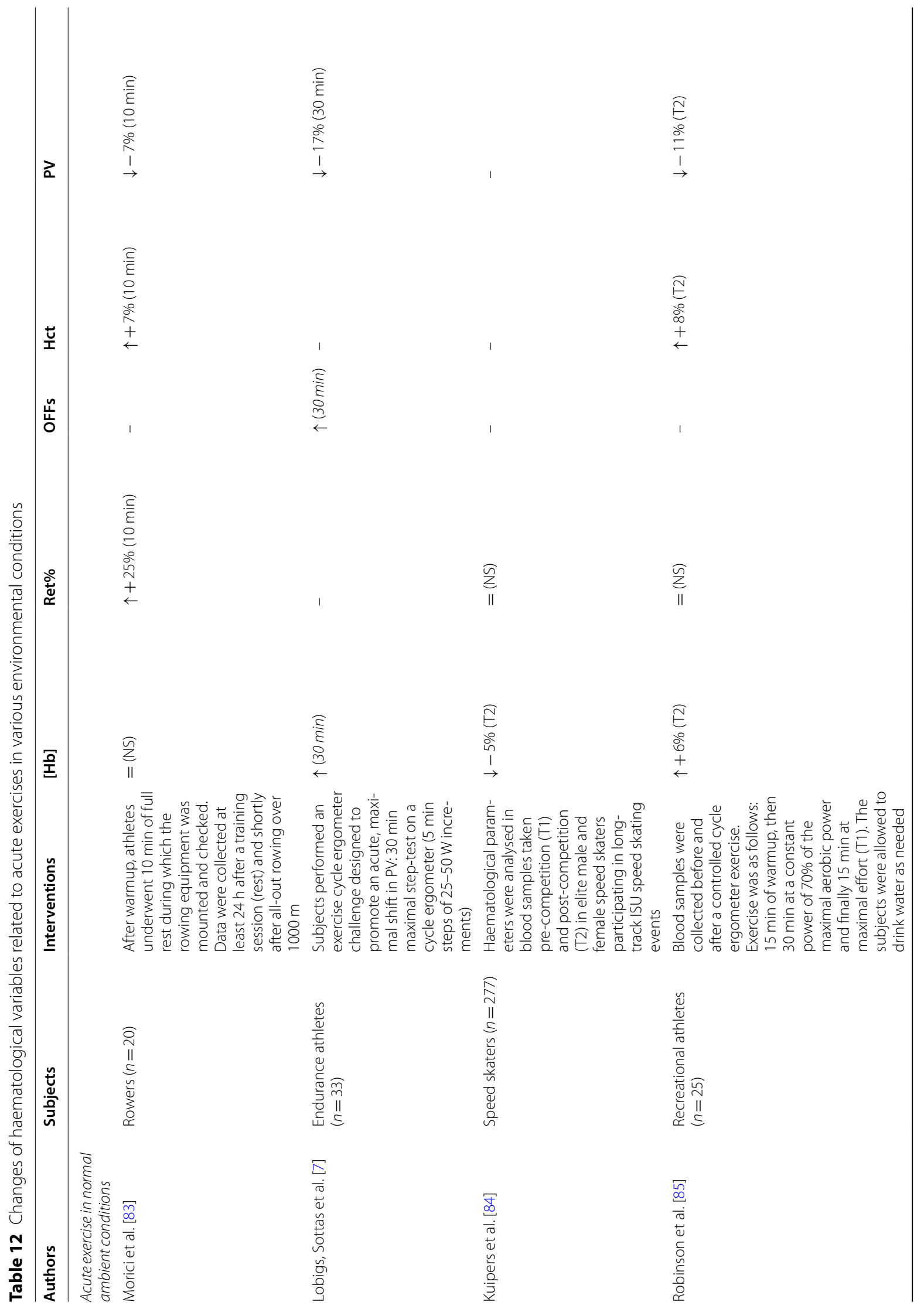




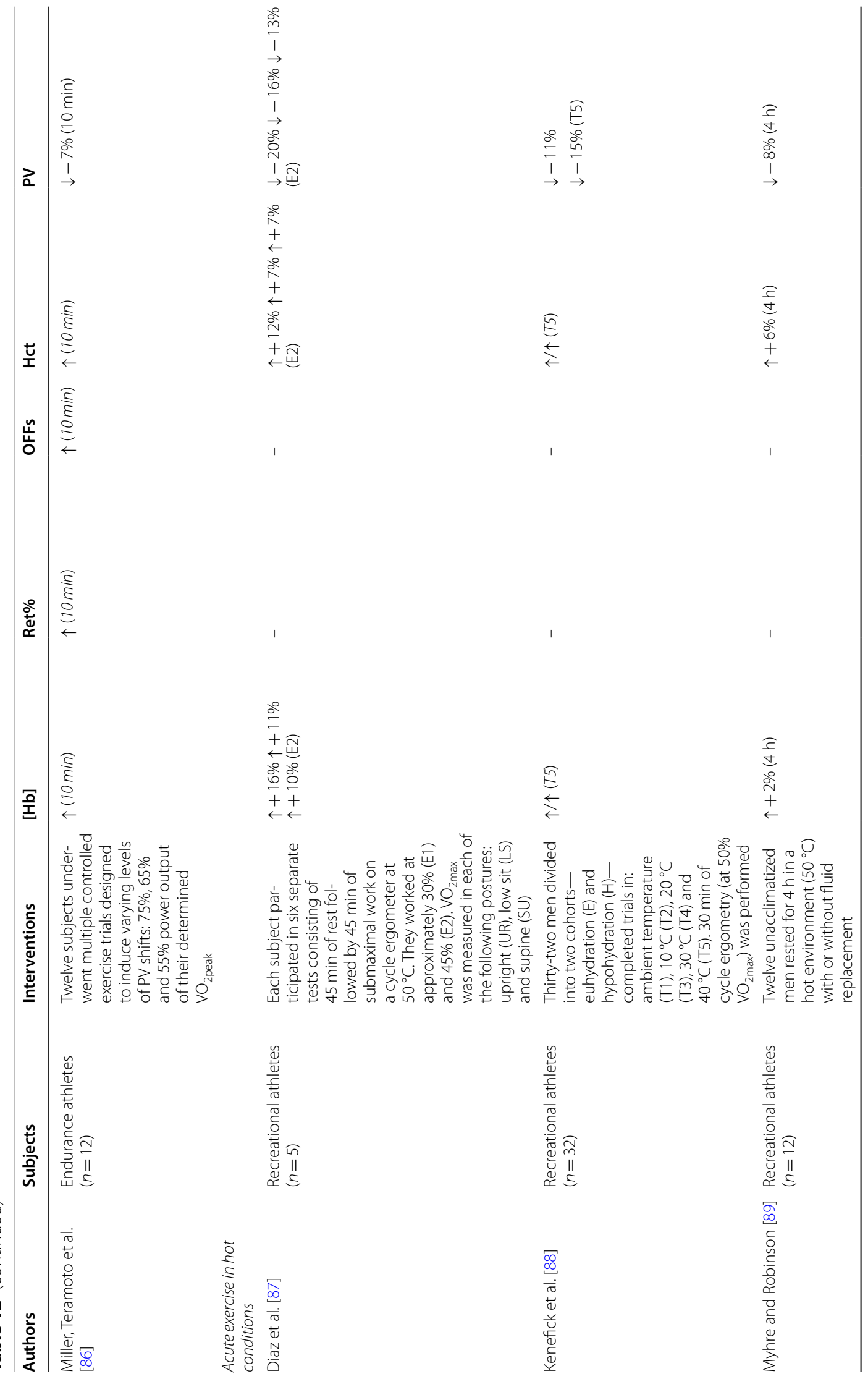




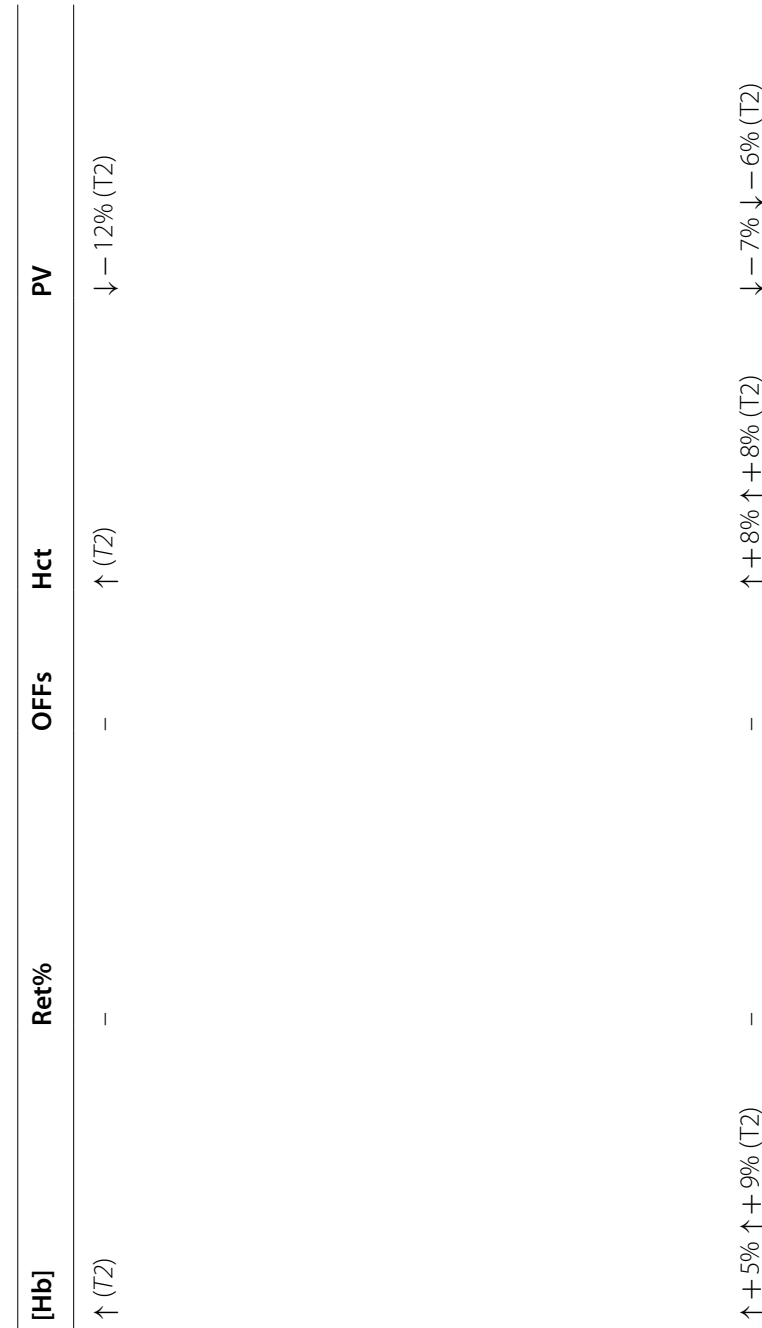

E
ò
ò
+
$\leftarrow$
ì
+
+
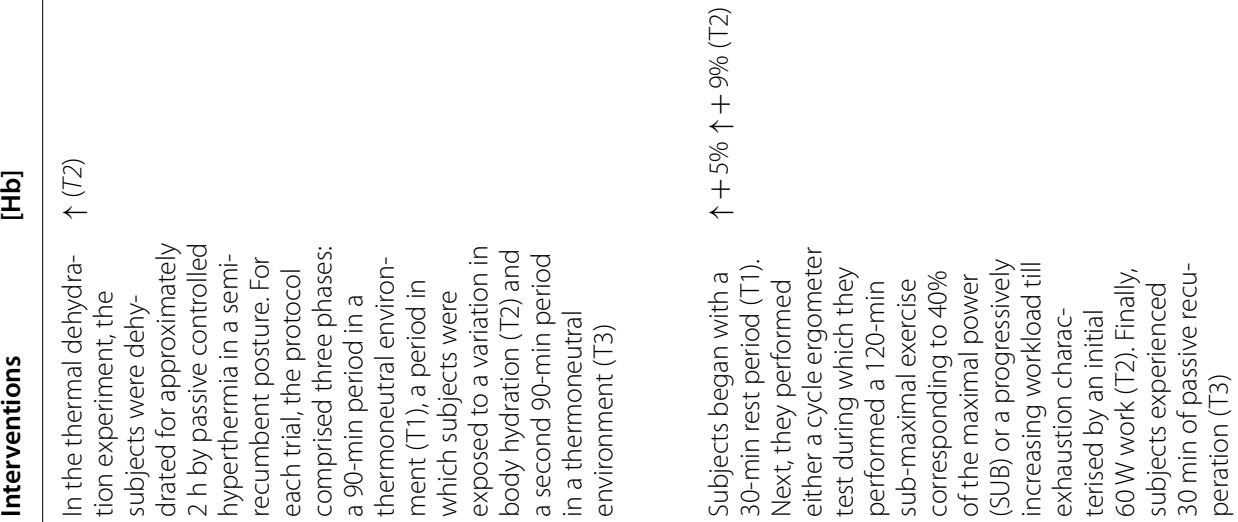

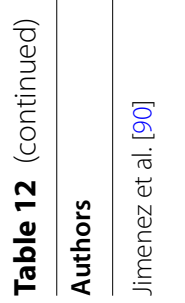

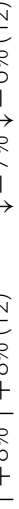

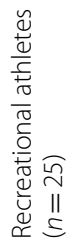

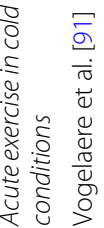




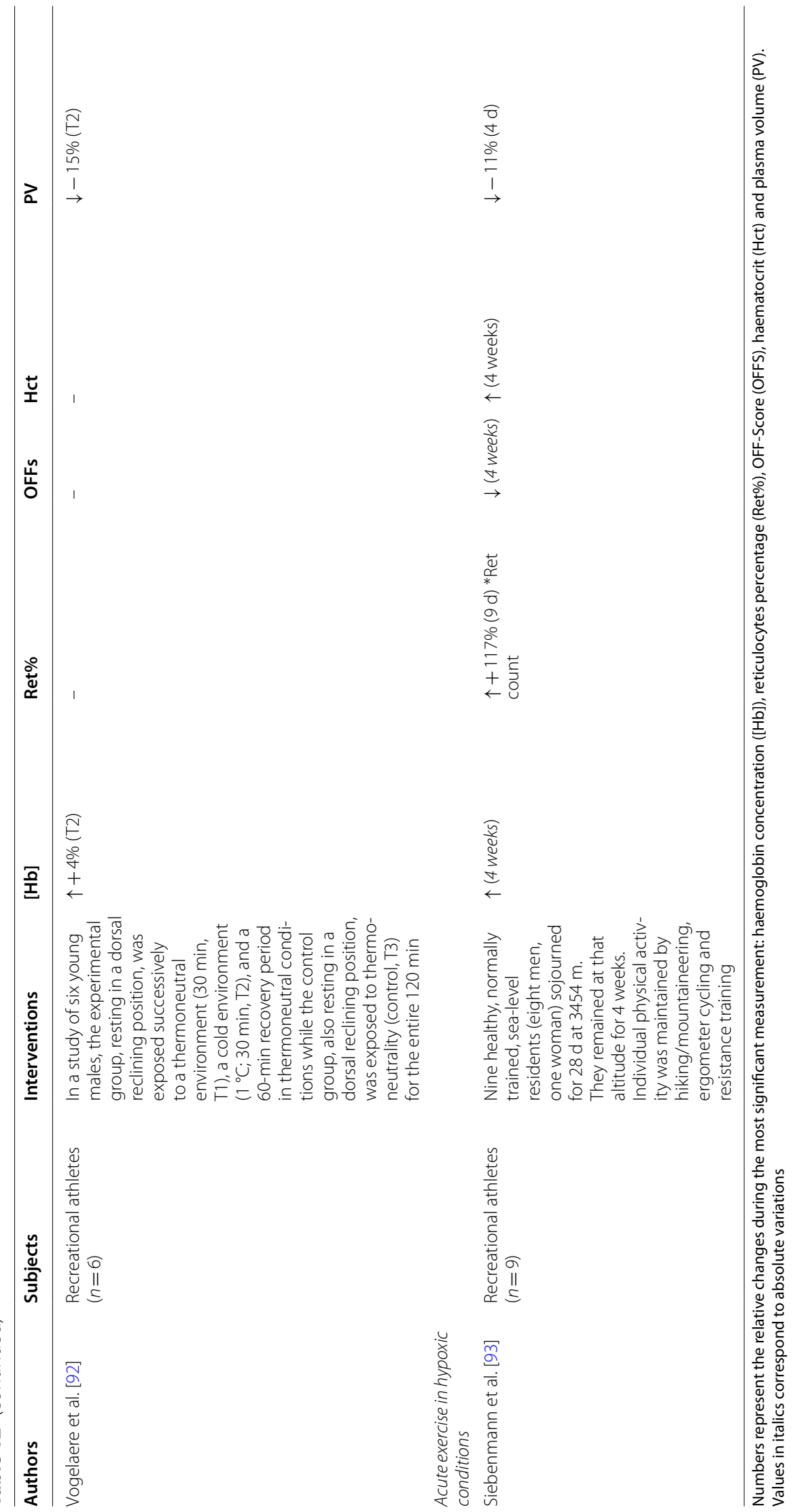


acclimation strategies $[8,100]$, and this increase is, in turn, often linked to [Hb] reduction [50-54]. Although PV varies after heat acclimatisation, such variation may also occur without influencing ABP values [55], depending on the type of acclimatisation strategy and subjects involved. Another form of exposure to extreme environments is dry sauna bathing [101], which resulted in some heat acclimation with a significant PV expansion (up to $\sim 15 \%)[52,53]$. A recent systematic review minimises the confounding risk of heat acclimation because no significant change in PV variations was reported after various acclimation protocols [102, 103]. Conversely, several sessions of whole-body cryotherapy were proposed to decrease [Hb] [56].

Hypoxia is another environmental condition now widely used by athletes [104] where [Hb] may be either not $[58,59]$ or only slightly affected [60] depending on the timing of blood sampling after living high-training high (LHTH) periods. Moreover, an increase in Ret\% was reported during hypoxic exposure [59, 61], while Ret\% decreased upon return to a lower altitude [58]. Similar blood variations were reported following living high-training low (LHTL) protocols with, however, a more pronounced increase in [Hb] [62-65]. Variations due to hypoxic training observed immediately after altitude exposure were reported to persist three weeks after returning to sea level $[58,62]$. In addition, intermittent hypoxic exposure (IHE) or training (IHT) may positively influence Ret\% [66]. Nevertheless, the rationale for the use of IHE for erythropoietic purposes in athletes is limited [105], and the response is inconsistent when hypoxic exposure is not prolonged $[67,68]$. Prolonged exposure to simulated or real altitude was reported to induce similar and prominent changes in total haemoglobin mass $\left(\mathrm{Hb}_{\text {mass }}\right)$ [106, 107]. Nevertheless, haematological variations following hypoxic training are contradictory [59, $104]$ and not systematically reported $[63,108]$, possibly due to initial fitness, initial fatigue or iron status [36, 109]. It seems unlikely, then, that training in a hypoxic environment could lead to a misinterpretation of an athlete's blood profiles [65] if duly reported in the doping control forms as requested by WADA.

Finally, specific individual characteristics were also shown to impact haematological components in athletes. Some haematological disorders were reported to alter $[\mathrm{Hb}]$, with these athletes exhibiting lower values than those of healthy athletes [69]. With some athletes suffering from haemochromatosis (a pathological condition requiring the withdrawal of large amounts of blood), [Hb] was decreased immediately after withdrawal [110] while a measurable increase in reticulocytes was sometimes delayed for a few days [70]. However, most haematological disorders observed in athletes were not associated with exceeding the limits of the model used to detect rhEPO [69]. Thus, the potential of these disorders to cause misinterpretation of the ABP profiles is limited. Finally, in contrast to Ret\%, which is frequently higher among women $[73,111],[\mathrm{Hb}]$ is known to be higher in men than in women. Ret\% was also shown to vary during the menstrual cycles of active women with lower values reported in the follicular phase [74]. Still, most of these variations remained within the individual ABP limits. Furthermore, one should be aware that individual characteristics (e.g., sex or ethnicity) used to define initial individual limits (i.e. possible inter-individual variance) then become irrelevant since the adaptive model focuses on intra-individual variation for the correct interpretation of an athlete's hematological profile.

Finally, while anti-doping blood samples are collected and analyzed following very strict guidelines [1], preanalytical and analytical variations [112] should not be excluded from the studies included in this review since results for hematological variables originate from different analysers and/or varying pre-analytical procedures.

\section{Conclusion}

As this review shows, the effects of ABP confounders vary widely in amplitude and duration depending on the type of effector (i.e. doping, environmental condition, training or pre-analytical condition). Nevertheless, the absolute effects of the factors described in this review appear to be relatively limited when taken together. Furthermore, true and systematic effects of environmental conditions (i.e. heat acclimation or hypoxic training) on haematological biomarkers remain debatable due to significant differences in individual responses [103, 104]. Studies investigating specific $\mathrm{ABP}$ confounders generally report variations within individual limits of the adaptive model [13, 63, 65, 97]. The scientific level of ABP experts reviewing passports and their efforts to do so with the latter factors in mind can further limit misinterpretations of ABP profiles caused by the confounding factors identified in this review. Nevertheless, many authors have noted an important inter- and intra-variability concerning haematological biomarkers $[111,112]$, highlighting the need to improve the sensitivity of the ABP while interpreting confounders carefully. The present review contributes to a detailed understanding of confounding factors that could affect ABP biomarkers. By reporting limited variation in haematological variables through the selected studies of this review, our findings support the blood module of the ABP as an efficient instrument to deter and indirectly detect doping. Nevertheless, further studies on the confounders that affect blood variables may contribute to improving the module and thus fighting doping more effectively. 


\begin{abstract}
Abbreviations
ABP: Athlete biological passport; ADAMS: Anti-doping administration and management system; APMU: Athlete passport management unit; ATPF: Atypical passport finding; [Hb]: Haemoglobin concentration; $\mathrm{Hb}_{\text {mass }}$ : Haemoglobin mass; Hct: Haematocrit; IHE: Intermittent hypoxic exposure; IHT: Intermittent hypoxic training; LHTH: Living high-training high; LHTL: Living high-training low; OFFs: OFF-score; PV: Plasma volume; Ret\%: Percentage of reticulocytes; WADA: World anti-doping agency.
\end{abstract}

\section{Acknowledgements}

Not applicable.

\section{Authors' contributions}

BK and RF conceived the project and designed the study. BK and RF contributed to the collection of data and interpreted the results. BK wrote the first draft of the manuscript. BK and RF contributed to revising the manuscript. BK and RF read and approved the final manuscript. All authors read and approved the final manuscript.

\section{Funding}

The authors received no financial support for the research, authorship, or publication of this article.

\section{Availability of data and materials}

Not applicable.

\section{Declarations}

\section{Ethics approval and Consent to participate}

The present systematic review only includes data from existing and published studies so that no specific ethics approval is required.

\section{Consent for publication}

Not applicable.

\section{Competing interests}

Bastien Krumm and Raphael Faiss declare that they have no conflicts of interest relevant to the content of this review.

\section{Author details}

${ }^{1}$ Institute of Sport Sciences, University of Lausanne, Lausanne, Switzerland. ${ }^{2}$ Center of Research and Expertise in Anti-Doping Sciences - REDs, University of Lausanne, Lausanne, Switzerland.

Received: 8 February 2021 Accepted: 28 August 2021

Published online: 15 September 2021

\section{References}

1. WADA. Athlete biological passport operating guidelines-version 7.1, June 2019 [Internet]. World Antidoping Agency; 2019 [cited 2020 Oct 1]. Available from: https://www.wada-ama.org/sites/default/files/resou rces/files/guidelines_abp_v71.pdf.

2. Saugy $M$, Leuenberger $N$. Antidoping: from health tests to the athlete biological passport. Drug Test Anal. 2020;12(5):621-8.

3. Sottas P-E, Robinson N, Saugy M. The Athlete's biological passport and indirect markers of blood doping. In: Thieme D, Hemmersbach P, editors. Doping in sports. Berlin, Heidelberg: Springer; 2009. p. 305-26. https://doi.org/10.1007/978-3-540-79088-4_14

4. Banfi G. Limits and pitfalls of Athlete's biological passport. Clinical Chemistry and Laboratory Medicine [Internet]. 2011 [cited 2020 Apr 14];49. Available from: https://www.degruyter.com/view/j/cclm.2011. 49.issue-9/cclm.2011.633/cclm.2011.633.xml.

5. Sottas P-E, Baume N, Saudan C, Schweizer C, Kamber M, Saugy M. Bayesian detection of abnormal values in longitudinal biomarkers with an application to T/E ratio. Biostatistics. 2007;8:285-96.

6. Kargotich S, Goodman C, Keast D, Morton AR. The influence of exerciseinduced plasma volume changes on the interpretation of biochemical parameters used for monitoring exercise, training and sport. Sports Med. 1998:26:101-17.

7. Lobigs LM, Sottas P-E, Bourdon PC, Nikolovski Z, El-Gingo M, Varamenti $E$, et al. A step towards removing plasma volume variance from the Athlete's Biological Passport: the use of biomarkers to describe vascular volumes from a simple blood test. Drug Test Anal. 2018;10:294-300.

8. Sawka MN, Convertino VA, Eichner ER, Schnieder SM, Young AJ. Blood volume: importance and adaptations to exercise training, environmental stresses, and trauma/sickness. Med Sci Sports Exerc. 2000;32:332.

9. Sanchis-Gomar F, Martinez-Bello VE, Gomez-Cabrera MC, Viña J. Current limitations of the Athlete's biological passport use in sports. Clinical Chemistry and Laboratory Medicine [Internet]. 2011 [cited 2020 Mar 16];49. Available from: https://www.degruyter.com/view/j/cclm.2011. 49.issue-9/cclm.2011.609/cclm.2011.609.xml.

10. WADA. Blood analytical requirements for the athlete biological passport TD2010BAR 1.0. 1.06.2019; Version 1.0. [Internet]. World Antidoping Agency; 2009 [cited 2020 Oct 1]. Available from: https://www.wadaama.org/sites/default/files/resources/files/guidelines_abp_v71.pdf.

11. WADA. Blood sample collection guidelines [Internet]. World Antidoping Agency; 2016 [cited 2020 Oct 1]. Available from: https://www.wadaama.org/sites/default/files/resources/files/guidelines_blood_sample_ collection_v4_0_2016_final_eng.pdf.

12. Kuuranne T, Saugy M, Baume N. Confounding factors and genetic polymorphism in the evaluation of individual steroid profiling. $\mathrm{Br} J$ Sports Med. 2014;48:848-55.

13. Astolfi T, Schumacher YO, Crettaz von Roten F, Saugy M, Faiss R. Does body position before and during blood sampling influence the Athlete Biological Passport variables? Int J Lab Hematol. 2020;42:61-7.

14. Wedin JO, Henriksson AE. The influence of floorball on hematological parameters: consequences in health assessment and antidoping testing. J Sports Med. 2020;2020:1-6.

15. Bejder J, Aachmann-Andersen NJ, Bonne TC, Olsen NV, Nordsborg NB. Detection of erythropoietin misuse by the athlete biological passport combined with reticulocyte percentage: sensitivity of the adaptive model of the athlete biological passport. Drug Test Anal. 2016:8:1049-55.

16. Bornø A, Aachmann-Andersen NJ, Munch-Andersen T, Hulston CJ, Lundby C. Screening for recombinant human erythropoietin using $[\mathrm{Hb}]$, reticulocytes, the OFFhr score, OFF z score and Hb z score: status of the Blood Passport. Eur J Appl Physiol. 2010;109:537-43.

17. Clark B, Woolford SM, Eastwood A, Sharpe K, Barnes PG, Gore CJ. Temporal changes in physiology and haematology in response to high- and micro-doses of recombinant human erythropoietin: temporal responses to high- and micro-doses of rHuEPO. Drug Test Anal. 2017;9:1561-71.

18. Ashenden M, Gough CE, Garnham A, Gore CJ, Sharpe K. Current markers of the athlete blood passport do not flag microdose EPO doping. Eur J Appl Physiol. 2011;111:2307-14.

19. Haile DW, Durussel J, Mekonen W, Ongaro N, Anjila E, Mooses M, et al. Effects of EPO on blood parameters and running performance in Kenyan athletes. Med Sci Sports Exerc. 2019;51:299-307.

20. Damsgaard R, Munch T, Morkeberg J, Mortensen SP, Gonzàlez-Alonso J. Effects of blood withdrawal and reinfusion on biomarkers of erythropoiesis in humans: implications for anti-doping strategies. Haematologica. 2006;91:1006-8.

21. Lamberti N, Finotti A, Gasparello J, Lampronti I, Zambon C, Cosenza LC, et al. Changes in hemoglobin profile reflect autologous blood transfusion misuse in sports. Intern Emerg Med. 2018;13:517-26.

22. Bejder J, Breenfeldt Andersen A, Solheim SA, Gybel-Brask M, Secher NH, Johansson PI, et al. Time trial performance is sensitive to low-volume autologous blood transfusion. Med Sci Sports Exerc. 2019;51:692-700.

23. Schmidt WFJ, Hoffmeister T, Haupt S, Schwenke D, Wachsmuth NB, Byrnes WC. Chronic exposure to low dose carbon monoxide alters hemoglobin mass and VO2max. Med Sci Sports Exerc. 2020. https://doi. org/10.1249/MSS.0000000000002330.

24. Sanchis-Gomar F, Martinez-Bello VE, Nascimento AL, Perez-Quilis C, Garcia-Gimenez JL, Viña J, et al. Desmopresssin and hemodilution: implications in doping. Int J Sports Med. 2010;31:5-9.

25. Dias KA, Lawley JS, Gatterer H, Howden EJ, Sarma S, Cornwell WK, et al. Effect of acute and chronic xenon inhalation on erythropoietin, 
hematological parameters, and athletic performance. J Appl Physiol. 2019;127:1503-10.

26. Miller GD, Beharry A, Teramoto M, Lai A, Willick SE, Eichner D. Hematological changes following an Ironman triathlon: an antidoping perspective. Drug Test Anal. 2019;11:1747-54.

27. Schumacher Y, Temme J, Bueltermann D, Schmid A, Berg A. The influence of exercise on serum markers of altered erythropoiesis and the indirect detection models of recombinant human erythropoietin abuse in athletes. Haematologica. 2003;88:712-4.

28. Fallon KE, Sivyer G, Sivyer K, Dare A. Changes in haematological parameters and iron metabolism associated with a 1600 kilometre ultramarathon. Br J Sports Med. 1999:33:27-31.

29. Mørkeberg J, Belhage B, Damsgaard R. Changes in blood values in elite cyclist. Int J Sports Med. 2009;30:130-8.

30. Voss S, Alsayrafi M, Bourdon P, Klodt F, Nonis D, Hopkins W, et al. Variability of serum markers of erythropoiesis during 6 days of racing in highly trained cyclists. Int J Sports Med. 2013;35:89-94.

31. Corsetti R, Lombardi G, Lanteri P, Colombini A, Graziani R, Banfi G. Haematological and iron metabolism parameters in professional cyclists during the Giro d'Italia 3-weeks stage race. Clin Chem Lab Med. 2012. https://doi.org/10.1515/cclm-2011-0857.

32. Lombardi G, Lanteri P, Fiorella PL, Simonetto L, Impellizzeri FM, Bonifazi $M$, et al. Comparison of the hematological profile of elite road cyclists during the 2010 and 2012 GiroBio ten-day stage races and relationships with final ranking. PLoS ONE. 2013;8:e63092.

33. Rama L, Minuzzi L, Carvalho H, Costa R, Teixeira A. Changes of hematological markers during a multi-stage ultra-marathon competition in the heat. Int J Sports Med. 2015;37:104-11.

34. Zappe DH, Tankersley CG, Meister TG, Kenny WL. Fluid restriction prior to cycle exercise: effects on plasma volume and plasma proteins. Med Sci Sports Exerc. 1993:25:1225-30

35. Gaebelein CJ, Senay LC. Influence of exercise type, hydration, and heat on plasma volume shifts in men. J Appl Physiol. 1980;49:119-23.

36. Garvican-Lewis LA, Schumacher YO, Clark SA, Christian R, Menaspà P, Plowman J, et al. Stage racing at altitude induces hemodilution despite an increase in hemoglobin mass. J Appl Physiol. 2014;117:463-72.

37. Schumacher YO, Garvican LA, Christian R, Lobigs LM, Qi J, Fan R, et al. High altitude, prolonged exercise, and the athlete biological passport: athlete biological passport, altitude, and exercise. Drug Test Anal. 2015;7:48-55.

38. Spodaryk K. Haematological and iron-related parameters of male endurance and strength trained athletes. Eur J Appl Physiol. 1993;67:66-70.

39. Bejder J, Andersen AB, Goetze JP, Aachmann-Andersen NJ, Nordsborg NB. Plasma volume reduction and hematological fluctuations in high-level athletes after an increased training load. Scand J Med Sci Sports. 2017;27:1605-15.

40. Green HJ, Sutton JR, Coates G, Ali M, Jones S. Response of red cell and plasma volume to prolonged training in humans. J Appl Physiol. 1991:70:1810-5.

41. Montero D, Breenfeldt-Andersen A, Oberholzer L, Haider T, Goetze $J$, Meinild-Lundby A-K, et al. Erythropoiesis with endurance training: dynamics and mechanisms. Am J Physiol Regul Integr Comp Physiol. 2017;312:R894-902.

42. Revelli L, Vagnoni S, D'Amore A, Di Stasio E, Lombardi C, Storti G, et al. EPO modulation in a 14-days undersea scuba dive. Int J Sports Med. 2013:34:856-60.

43. Banfi G, Del Fabbro M. Behaviour of reticulocyte counts and immature reticulocyte fraction during a competitive season in elite athletes of four different sports: reticulocytes in athletes. Int I Lab Hematol. 2007;29:127-31.

44. Abellan R, Ventura R, Pichini S, Palmi I, Bellver M, Olive R, et al. Effect of physical fitness and endurance exercise on indirect biomarkers of recombinant erythropoietin misuse. Int J Sports Med. 2007;28:9-15.

45. Malcovati L, Pascutto C, Cazzola M. Hematologic passport for athletes competing in endurance sports: a feasibility study. Haematologica. 2003:88:12.
46. Banfi G, Del Fabbro M, Mauri C, Corsi MM, Melegati G. Haematological parameters in elite rugby players during a competitive season. Clin Lab Haematol. 2006;28:183-8.

47. Banfi G, Tavana R, Freschi M, Lundby C. Reticulocyte profile in top-level alpine skiers during four consecutive competitive seasons. Eur J Appl Physiol. 2010;109:561-8.

48. Mujika I, Goya A, Padilla S, Grijalba A, Gorostiaga E, Ibanez J. Physiological responses to a 6-d taper in middle-distance runners: influence of training intensity and volume. Med Sci Sports Exerc. 2000;32:511.

49. Mujika I, Goya A, Ruiz E, Grijalba A, Santisteban J, Padilla S. Physiological and performance responses to a 6-day taper in middle-distance runners: influence of training frequency. Int J Sports Med. 2002;23:367-73.

50. Costa RJS, Crockford MJ, Moore JP, Walsh NP. Heat acclimation responses of an ultra-endurance running group preparing for hot desert-based competition. Eur J Sport Sci. 2014;14:S131-41.

51. Loeppky J. Plasma volume after heat acclimation: variations due to season, fitness and methods of measurement. Acta Physiol Hung. 2015;102:282-92.

52. Scoon GSM, Hopkins WG, Mayhew S, Cotter JD. Effect of post-exercise sauna bathing on the endurance performance of competitive male runners. J Sci Med Sport. 2007;10:259-62.

53. Stanley J, Halliday A, D'Auria S, Buchheit M, Leicht AS. Effect of saunabased heat acclimation on plasma volume and heart rate variability. Eur J Appl Physiol. 2015;115:785-94.

54. Tebeck ST, Buckley JD, Bellenger CR, Stanley J. Differing physiological adaptations induced by dry and humid short-term heat acclimation. Int J Sports Physiol Perform. 2020;15:133-40.

55. Oberholzer L, Siebenmann C, Mikkelsen CJ, Junge N, Piil JF, Morris NB, et al. Hematological adaptations to prolonged heat acclimation in endurance-trained males. Front Physiol. 2019;10:1379.

56. Banfi G, Krajewska M, Melegati G, Patacchini M. Effects of whole-body cryotherapy on haematological values in athletes. Br J Sports Med. 2008:42:858.

57. Checinska-Maciejewska Z, Niepolski L, Checinska A, Korek E, Kolodziejczak B, Kopczynski Z, et al. Regular cold water swimming during winter time affects resting hematological parameters and serum erythropoietin. J Physiol Pharmacol. 2019;70:747-56.

58. Bonne TC, Lundby C, Lundby AK, Sander M, Bejder J, Nordsborg NB. Altitude training causes haematological fluctuations with relevance for the athlete biological passport: altitude training and the athlete biological passport. Drug Test Anal. 2015;7:655-62.

59. Garvican L, Martin D, Quod M, Stephens B, Sassi A, Gore C. Time course of the hemoglobin mass response to natural altitude training in elite endurance cyclists: altitude training and hemoglobin mass. Scand J Med Sci Sports. 2012;22:95-103.

60. Wachsmuth NB, Völzke C, Prommer N, Schmidt-Trucksäss A, Frese F, Spahl O, et al. The effects of classic altitude training on hemoglobin mass in swimmers. Eur J Appl Physiol. 2013;113:1199-211.

61. Ashenden MJ, Hahn AG, Martin DT, Logan P, Parisotto R, Gore CJ. A comparison of the physiological response to simulated altitude exposure and r-HuEpo administration. J Sports Sci. 2001;19:831-7.

62. Ashenden MJ, Gore CJ, Parisotto R, Sharpe K, Hopkins WG, Hahn AG. Effect of altitude on second-generation blood tests to detect erythropoietin abuse by athletes. Haematologica. 2003;88:1053-1052.

63. Garvican-Lewis LA, Vuong VL, Govus AD, Schumacher YO, Hughes D, Lovell G, et al. Influence of combined iron supplementation and simulated hypoxia on the haematological module of the athlete biological passport. Drug Test Anal. 2018;10:731-41.

64. Neya M, Enoki T, Ohiwa N, Kawahara T, Gore CJ. Increased hemoglobin mass and VO2max With $10 \mathrm{~h}$ nightly simulated altitude at $3000 \mathrm{~m}$. Int J Sports Physiol Perform. 2013;8:366-72.

65. Voss SC, Al-Hamad K, Samsam W, Cherif A, Georgakopoulos C, Al Maadheed $\mathrm{M}$, et al. A novel mixed living high training low intervention and the hematological module of the athlete biological passport. Drug Test Anal. 2019;12(3):323-30.

66. Kasperska A, Zembron-Lacny A. The effect of intermittent hypoxic exposure on erythropoietic response and hematological variables in 
elite athletes. Physiol Res. 2020. https://doi.org/10.33549/physiolres. 934316.

67. Abellan R, Ventura R, Remacha AF, Rodríguez FA, Pascual JA, Segura J. Intermittent hypoxia exposure in a hypobaric chamber and erythropoietin abuse interpretation. J Sports Sci. 2007;25:1241-50.

68. Sanchez AMJ, Borrani F. Effects of intermittent hypoxic training performed at high hypoxia level on exercise performance in highly trained runners. J Sports Sci. 2018;36:2045-52.

69. Parisotto R, Ashenden MJ, Gore CJ, Sharpe K, Hopkins W, Hahn AG. The effect of common hematologic abnormalities on the ability of blood models to detect erythropoietin abuse by athletes. Haematologica. 2003;88(8):931-40.

70. Stangerup I, Kramp NL, Ziegler AK, Dela F, Magnussen K, Helge JW. Temporary impact of blood donation on physical performance and hematologic variables in women: blood donation and performance in women. Transfusion. 2017;57:1905-11.

71. Meurrens J. Effect of repeated whole blood donations on aerobic capacity and hemoglobin mass in moderately trained male subjects: a randomized controlled trial. Sports Med. 2016;2:12.

72. Ryan BJ, Goodrich JA, Schmidt WF, Stothard ER, Wright KP, Byrnes WC. Haemoglobin mass alterations in healthy humans following four-day head-down tilt bed rest. Exp Physiol. 2016;101:628-40.

73. Robinson N, Saugy J, Schütz F, Faiss R, Baume N, Giraud S, et al. Worldwide distribution of blood values in elite track and field athletes: Biomarkers of altered erythropoiesis. Drug Test Anal. 2019;1 1:567-77.

74. Mullen J, Bækken L, Bergström H, Björkhem Bergman L, Ericsson M, Ekström L. Fluctuations in hematological athlete biological passport biomarkers in relation to the menstrual cycle. Drug Test Anal. 2020;12(9):1229-40

75. Lobigs $L$. The development of athlete-specific hematological reference intervals and the effect of ethnicity on key hematological markers. In: Qatar foundation annual research forum proceedings. 2013;BIOSP 07.

76. Steiner T, Wehrlin JP. Does hemoglobin mass increase from age 16 to 21 and 28 in elite endurance athletes? Med Sci Sports Exerc. 2011:43:1735-43.

77. Steiner T, Maier T, Wehrlin JP. Effect of endurance training on hemoglobin mass and VO2max in male adolescent athletes. Med Sci Sports Exerc. 2019;51:912-9.

78. Sennels HP, Jørgensen HL, Hansen A-LS, Goetze JP, Fahrenkrug J. Diurnal variation of hematology parameters in healthy young males: the Bispebjerg study of diurnal variations. Scand I Clin Lab Investig. 2011;71:532-41.

79. Kuipers H, Brouwer T, Dubravcic-Simunjak S, Moran J, Mitchel D, Shobe $J$, et al. Hemoglobin and hematocrit values after saline infusion and tourniquet. Int J Sports Med. 2005;26:405-8.

80. Bejder J, Hoffmann MF, Ashenden M, Nordsborg NB, Karstoft K, Mørkeberg J. Acute hyperhydration reduces athlete biological passport OFF-hr score: hyperhydration and athlete biological passport. Scand J Med Sci Sports. 2016;26:338-47.

81. Schumacher YO, Klodt F, Nonis D, Pottgiesser T, Alsayrafi M, Bourdon PC, et al. The impact of long-haul air travel on variables of the athlete's biological passport. Int I Lab Hematol. 2012;34:641-7.

82. Alsaadi K, Voss SC, Kraiem S, Alwahaibi A, Alyazedi S, Dbes N, et al. The effect of fasting during Ramadan on parameters of the haematological and steroidal modules of the athletes biological passport-a pilot study. Drug Testing. 2015;7:1017-24.

83. Morici G, Zangla D, Santoro A, Pelosi E, Petrucci E, Gioia M, et al. Supramaximal exercise mobilizes hematopoietic progenitors and reticulocytes in athletes. Am J Physiol Regul Integr Comp Physiol. 2005;289:R1496-503.

84. Kuipers H, Dubravcic-Simunjak S, Moran J, Mitchell D, Shobe J, Sakai H, et al. Blood testing in sport: hematological profiling. Int J Sports Med. 2010;31:542-7.

85. Robinson N, Saugy M, Mangin P. Effects of exercise on the secondary blood markers commonly used to suspect erythropoietin doping. Clin Lab. 2003:49:57-62.

86. Miller GD, Teramoto M, Smeal SJ, Cushman D, Eichner D. Assessing serum albumin concentration following exercise-induced fluid shifts in the context of the athlete biological passport. Drug Test Anal. 2019;11:782-91.

87. Diaz FJ, Bransford DR, Kobayashi K, Horvath SM, McMurray RG. Plasma volume changes during rest and exercise in different postures in a hot humid environment. J Appl Physiol. 1979;47:798-803.

88. Kenefick RW, Sollanek KJ, Charkoudian N, Sawka MN. Impact of skin temperature and hydration on plasma volume responses during exercise. J Appl Physiol. 2014;117:413-20.

89. Myhre LG, Robinson S. Fluid shifts during thermal stress with and without fluid replacement. J Appl Physiol. 1977;42:252-6.

90. Jimenez C, Melin B, Koulmann N, Allevard AM, Launay JC, Savourey $G$. Plasma volume changes during and after acute variations of body hydration level in humans. Eur J Appl Physiol. 1999;80:1-8.

91. Vogelaere P, Brasseur M, Quirion A, Leclercq R, Laurencelle L, Bekaert S Hematological variations at rest and during maximal and submaximal exercise in a cold environment. Int J Biometeorol. 1990;34:1-14.

92. Vogelaere P, Savourey G, Deklunder G, Lecroart J, Brasseur M, Bekaert $\mathrm{S}$, et al. Reversal of cold induced haemoconcentration. Europ J Appl Physiol. 1992;64:244-9.

93. Siebenmann C, Cathomen A, Hug M, Keiser S, Lundby AK, Hilty MP, et al. Hemoglobin mass and intravascular volume kinetics during and after exposure to 3,454-m altitude. J Appl Physiol. 2015;1 19:1194-201.

94. Sutehall S, Martin-Rincon M, Wang G, Shurlock J, Durussel J, Mooses $M$, et al. The performance effects of microdose recombinant human erythropoietin administration and carbon monoxide rebreathing. Curr Sports Med Rep. 2018;17:457-66.

95. Frampas C, Augsburger M, Varlet V. Xenon: from medical applications to doping uses. Toxicol Anal Clin. 2017;29:309-19.

96. Solheim SA, Bejder J, Breenfeldt Andersen A, Mørkeberg J, Nordsborg NB. Autologous blood transfusion enhances exercise performancestrength of the evidence and physiological mechanisms. Sports Med Open. 2019;5:30.

97. Astolfi T, Crettaz von Roten F, Kayser B, Saugy M, Faiss R. The influence of training load on hematological athlete biological passport variables in elite cyclists. Sports Med. 2020. https://doi.org/10.1101/2020.10.22. 20213413.

98. Baranauskas MN, Constantini K, Paris HL, Wiggins CC, Schlader ZJ, Chapman RF. Heat versus altitude training for endurance performance at sea level. Exerc Sport Sci Rev. 2021;49:50-8.

99. Saunders PU, Garvican-Lewis LA, Chapman RF, Périard JD. Special environments: altitude and heat. Int I Sport Nutr Exerc Metab. 2019:29:210-9.

100. Périard JD, Travers GJS, Racinais S, Sawka MN. Cardiovascular adaptations supporting human exercise-heat acclimation. Auton Neurosci. 2016;196:52-62.

101. Hussain J, Cohen M. Clinical effects of regular dry sauna bathing: a systematic review. Evid Based Complement Altern Med. 2018;2018:1-30.

102. Corbett J, Rendell RA, Massey HC, Costello JT, Tipton MJ. Inter-individual variation in the adaptive response to heat acclimation. J Therm Biol. 2018;74:29-36.

103. Rahimi GRM, Albanaqi AL, Van der Touw T, Smart NA. Physiological responses to heat acclimation: a systematic review and meta-analysis of randomized controlled trials. J Sports Sci Med. 2019;18:316-26.

104. Płoszczyca K, Langfort J, Czuba M. The effects of altitude training on erythropoietic response and hematological variables in adult athletes: a narrative review. Front Physiol. 2018;9:375.

105. Faiss R, Girard O, Millet GP. Advancing hypoxic training in team sports: from intermittent hypoxic training to repeated sprint training in hypoxia: Table 1. Br J Sports Med. 2013;47:145-50.

106. Hauser A, Schmitt L, Troesch S, Saugy JJ, Cejuela-Anta R, Faiss R, et al. Similar hemoglobin mass response in hypobaric and normobaric hypoxia in athletes. Med Sci Sports Exerc. 2016;48:734-41.

107. Saugy JJ, Schmitt L, Hauser A, Constantin G, Cejuela R, Faiss R, et al. Same performance changes after live high-train low in normobaric vs. hypobaric hypoxia. Front Physiol. 2016. https://doi.org/10.3389/fphys. 2016.00138/abstract.

108. Siebenmann C, Robach P, Jacobs RA, Rasmussen P, Nordsborg N, Diaz V, et al." "Live high-train low" using normobaric hypoxia: a double-blinded, placebo-controlled study. J Appl Physiol. 2012;112:106-17. 
109. Lobigs LM, Sharpe K, Garvican-Lewis LA, Gore CJ, Peeling P, Dawson B, et al. The athlete's hematological response to hypoxia: A meta-analysis on the influence of altitude exposure on key biomarkers of erythropoiesis. Am J Hematol. 2018;93:74-83.

110. Johnson DM, Roberts J, Gordon D. The acute effects of whole blood donation on cardiorespiratory and haematological factors in exercise: a systematic review. PLoS ONE. 2019;14:e0215346.

111. Lombardi G, Colombini A, Lanteri P, Banfi G. Reticulocytes in sports medicine: an update. Adv Clin Chem. 2013:59:125-53.
112. Lippi G, Banfi G, Maffulli N. Preanalytical variability: the dark side of the moon in blood doping screening. Eur J Appl Physiol. 2010;109:1003-5.

\section{Publisher's Note}

Springer Nature remains neutral with regard to jurisdictional claims in published maps and institutional affiliations.

\section{Submit your manuscript to a SpringerOpen ${ }^{\circ}$ journal and benefit from:}

- Convenient online submission

- Rigorous peer review

- Open access: articles freely available online

- High visibility within the field

- Retaining the copyright to your article

Submit your next manuscript at $\boldsymbol{\nabla}$ springeropen.com 